\title{
THE CONTRASTING APPROACHES TO POWER OF THE MODERN STATE AND THE ANTITRUST LAWS: LESSONS FOR PLATFORM REGULATION
}

\author{
Ramsi A. Woodcock ${ }^{*}$
}

\begin{abstract}
If the state is a force monopolist, as Max Weber famously claimed, then the law is a kind of antitrust policy, with criminal law securing the state's monopoly on force and constitutional law regulating the exercise of the force monopolist's power primarily through the right to vote, which makes of the state the equivalent of a consumer cooperative dedicated to the production of security. One consequence of the cooperative approach is that the state's approach to vertical integration - in this context state ownership of enterprise - has mirrored antitrust's own approach to the vertical integration of private firms: to authorize integration only where it is likely to benefit consumers, which is rarely when the monopolist sells security, but often in the case of most products sold by private enterprise. Another consequence, low tax rates, differs greatly from antitrust's own approach to private enterprise, which broadly exempts the charging of high prices from liability. This difference in approach offers a useful lesson for antitrust policy, particularly in the area of digital platforms: that the heart of monopoly power is price, and the best way to dull the power of the platform monopolist is to regulate the prices it can charge and leave the question whether to permit it to integrate vertically to be decided on efficiency grounds. This suggests that the rule proposed by Senator Elizabeth Warren, that no big firm should be allowed to compete on its own platform, which amounts to a prohibition on vertical integration, is likely to be unhelpful. A better approach would be to regulate the fees platforms charge competitors and consumers and allow the tech giants to integrate when doing so would benefit consumers.
\end{abstract}

\footnotetext{
* Assistant Professor, University of Kentucky Rosenberg College of Law, Secondary Appointment, Department of Management, University of Kentucky Gatton College of Business \& Economics. This research was supported by a grant from the John S. and James L. Knight Foundation. Jennifer Bird-Pollan, Christopher Bradley, Matthew Bruckner, Brian Frye, Alan Kluegel, Carla Reyes, Jonathan Shaub, and participants at the 15th Academic Society for Competition Law (Virtual) Conference and the 2020 National Business Law Scholars Conference provided helpful comments.
} 


\section{Table of Contents}

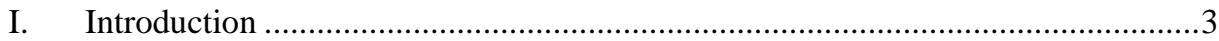

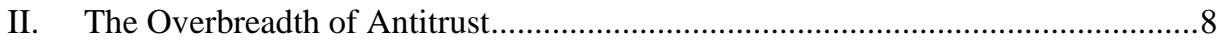

A.Antitrust Regulation of the Acquisition and Exercise of Power ............................ 9

B. Antitrust's Definition of Market Power Is Not Limited to Business Conduct.....14

C. Antitrust's Rules Regarding the Exercise of Power Are Not Limited to Business

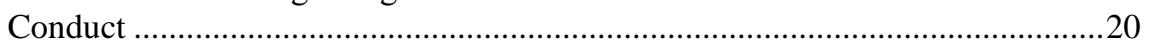

D.The Other Branches of Law Also Regulate Market Power ................................25

III. The Differing Approaches of Antitrust and the State to Power ........................33

A.The Acquisition of Power....................................................................................33

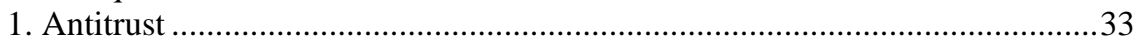

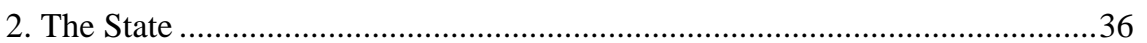

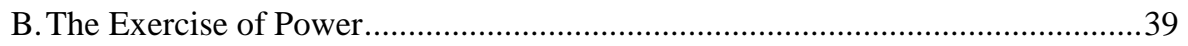

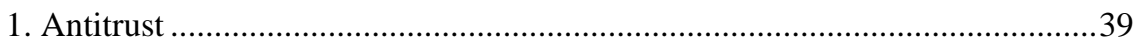

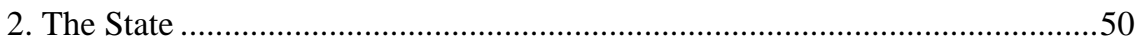

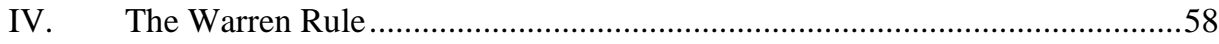

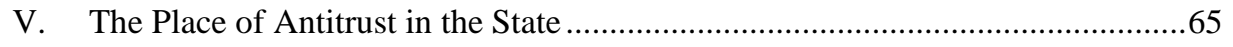

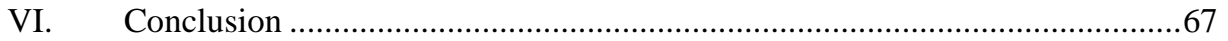




\section{INTRODUCTION}

The origin of all state power lies in the state's monopoly on the use of force. ${ }^{1}$ Constitutional law, and public law more generally, limit the conduct of that monopoly and define its boundaries. ${ }^{2}$ The antitrust laws have the same function, regulating the acquisition and exercise of monopoly power, except that the antitrust laws regulate all monopolies other than the force monopoly. ${ }^{3}$ The definition of power employed by the antitrust laws is so broad, however, that they could be applied to regulate the state, and indeed to achieve the same ends as all public law, if tradition, and the existence of more narrowlytailored public law limitations, did not keep the antitrust laws at bay. ${ }^{4}$

To be sure, antitrust purports to regulate only "the power profitably to raise price," and "price" and "profit" appear to limit the definition to the business context. ${ }^{5}$ By contrast, the state's exercises of power do not always consist of a demand for payment. But "price" in antitrust's definition of power can be anything of value, not just dollars and cents. ${ }^{6}$ And profit means

\footnotetext{
${ }^{1}$ See infra Section II.D.

${ }^{2}$ See infra Sections II.D, III.A.2, III.B.1.a.

${ }^{3}$ See John B. Kirkwood, Market Power and Antitrust Enforcement 1172 (2017) (stating that "[m]arket power . . . lies at the core of antitrust law"); HERBERT HOVENKAMP, FEDERAL ANTITRUST POLICY, THE LAW OF COMPETITION AND ITS PRACTICE 103-4 (6th ed. 2020) (identifying the many ways in which monopoly power factors into antitrust analysis in the United States); Phillip E. Areeda \& Herbert Hovenkamp, Antitrust LAw: AN ANALYSIS OF ANTITRUST PRINCIPLES AND THEIR APPLICATION II 240b (4th ed. 2020) (stating that "when a government agent with jurisdiction compels or approves certain behavior, it is not antitrust's job to interfere, notwithstanding our belief that the behavior is anticompetitive or inefficient, or that welfare would be better served if competition rather than regulation controlled this particular actor").

${ }^{4}$ Constitutionally-guaranteed rights, such as the right vote and to be free of unreasonable searches and seizures, are such tailored limitations. See infra Section II.D. In jurisdictions in which the antitrust laws are statutory law, as in the United States, any action brought against the government under those laws could be eliminated by an act of the legislature, which creates the antitrust laws and can make them go away. See 15 U.S.C. $\S \S 1,2$ (2018) (being the principal antitrust statutes in the United States). The argument here is not that, as a legal matter, the antitrust law always do give rise to a right of action against government or other non-businesses. The argument is that the definition of power contained in the antitrust laws would support suits against any entity having political power, even if such suits would be impossible to bring because of other legal rules, such as rules government antitrust standing. 5 See Kirkwood, supra note 3, at 1172 n.12 ("This definition is so widely used it is canonical.").

${ }^{6}$ See Joshua D. Wright \& Douglas H. Ginsburg, The Goals of Antitrust: Welfare Trumps Choice, 81 FORDHAM L. REV. 2405, 2410 n.32 (2013). This is the content of the qualityadjusted price approach taken by enforcers determining whether mergers will harm competition. Under quality-adjusted price analysis, the non-price attributes of products are
} 
only that when a firm increases its price, or otherwise shifts its terms of dealing, the firm must enjoy some net benefit as a result. ${ }^{7}$ But the ability to impose terms on others and end up ahead is precisely the general definition of all power, whether business power or state power, that most observers would embrace. ${ }^{8}$ The power to order a man to his death in battle, and not have him turn around and strike you down, or foment rebellion, is no more than that.

The expansive character of antitrust's definition of power makes it possible to compare antitrust's approach to the acquisition and exercise of power with the approach of constitutional law and public law more generally to the force monopoly that is the state, a comparison that holds important lessons for current debates over the future of the antitrust laws. ${ }^{9}$ In contrast to premodern conceptions of the state, which allowed the state direct ownership over production in a manner that can reasonably be called central planning, modern conceptions of the state assume a separation between the force monopoly and most of the production processes that take security as an essential input. ${ }^{10}$ In the language of antitrust, modern conceptions of the state frown on the vertical integration of the state as monopolist of force down into

understood to influence the overall value of a product to the consumer. Thus a firm that can reduce the quality of its product might under this analysis have market power, despite being unable to raise the product's price, so long as the reduction in product quality leads to a substantial reduction in costs of production and therefore to a substantial increase in the firm's profits. But all reductions in product quality may be conceptualized as representing offsetting payments to the seller of goods or services, rather than a money price. So, for example, if a restaurant eliminates table service, restaurant customers effectively supply labor services to the restaurant in serving themselves. The quality reduction of the restaurant's product is equivalent to an increase in the value demanded by the restaurant from the patron, a value to be paid not in dollars and cents but in labor. The notion that a firm's ability to raise quality-adjusted price reflects monopoly power is therefore equivalent to the view that a firm's ability to demand an increase in consumer payments in the form of goods and services, rather than money, can reflect monopoly power as well.

${ }^{7}$ See infra Section II.B.

${ }^{8}$ See infra Section II.B.

9 See infra Part III. Public law includes all areas of law that determine the relationship between the state and the individual. Examples are constitutional law, administrative law, and criminal law.

${ }^{10}$ Compare Jerome Blum, The Rise of Serfdom in Eastern Europe, 62 AM. HIST. REV. 807, 810 (1957) (observing that "one feature common to European serfdom wherever and whenever it existed" was that "the lord had legal jurisdiction over his peasants to the complete, or nearly complete, exclusion of the state, so that to all intents and purposes the only rights the peasants had were those that the lord was willing to allow them" and that "[a]t the beginning of the twelfth century most of the peasants in Western Europe were serfs") with U.S. Const. amend. XIII $\S 1$ ("Neither slavery nor involuntary servitude . . . shall exist within the United States[.]") 
the rest of the economy. ${ }^{11}$

This restriction on vertical integration is constitutive of the free enterprise approach to capitalism, and some would say even of capitalism itself. ${ }^{12}$ Indeed, activists arguing for more vigorous enforcement of antitrust laws have long attempted to draw an analogy between freedom from state power and freedom from corporate power. ${ }^{13}$ Senator Elizabeth Warren's proposal that no large firm be permitted to compete on its own platform - that Amazon, for example, should not be permitted to sell its own products on Amazon.com alongside those of third parties - appears to be based on that analogy. ${ }^{14}$ The platform owner plays the role of the government, and Senator Warren's rule would prevent the platform from owning any of the enterprises that compete upon it for the same reasons for which economic liberals oppose state intervention in markets: that the platform will use its power over the essential input that is the platform to favor its own enterprises and thereby to enrich itself at the expense of the public. ${ }^{15}$

It is an inconvenient fact, however, that the vertical disintegration of the modern state from the means of production is not actually an explicit matter of public law, other than in the area of labor. ${ }^{16}$ The U.S. Constitution does

${ }^{11} C f$. HovenKAMP, supra note 3, at 505-11 (discussing antitrust policy toward vertical mergers).

12 See Arthur Cecil Pigou, Socialism versus CAPitalism 1 (1949) ("A capitalist industry is one in which the material instruments of production are owned or hired by private persons and are operated at their orders with a view to selling at a profit the goods or services that they help to produce.").

${ }^{13}$ See, e.g., Talib Visram, This Man Says Big Tech is 'the Greatest Threat to Democracy since the Civil War, ' FAST COMPANY, https://www.fastcompany.com/90416600/this-mansays-big-tech-is-the-greatest-threat-to-democracy-since-the-civil-war (last visited Nov. 29, 2019) (quoting Barry Lynn stating that "competition policy is how you achieve democracy and liberty").

${ }^{14}$ See Team Warren, Here's How We Can Break up Big Tech, TEAM WARREN (Mar. 8, 2019), https://medium.com/@teamwarren/heres-how-we-can-break-up-big-tech-9ad9e0da324c (proposing that "platform utilities" be "prohibited from owning both the platform utility and any participants on that platform" if the platform utility has "annual global revenue of \$25 billion or more" and identifying "Amazon Marketplace, Google's ad exchange, and Google Search" as platform utilities); Anti-Monopoly and Competition Restoration Act of __ $\S$ 6(b)(4)(D), 6(b)(7)(E) (Draft Copy of SIL19C37) .

15 See David E.M. Sappington \& J. Gregory Sidak, Competition Law for State-Owned Enterprises, 71 ANTITRUST L.J. 479, 516 (2003) (arguing that state-owned enterprises are more likely to behave anticompetitively than are privately-owned firms because state-owned enterprises can often rely on the power of the state to exclude competitors through monopoly privileges and can also draw on tax revenues to under-price competitors).

${ }^{16}$ See Green v. Frazier, 253 U.S. 233, 240 (Supreme Court 1920) (ruling constitutional North Dakota's creation of a state "Industrial Commission" that owned a bank, warehouses, factories and construction enterprises and observing that "[w]ith the wisdom of such legislation, and the soundness of the economic policy involved we are not concerned"); 
not, for example, prohibit state ownership of the means of production and indeed the state does intervene, in a limited way, in a host of supply chains, from transportation to mail delivery. ${ }^{17}$ Instead, the tendency of the modern state vertically to disintegrate from the means of production is a consequence of a core right of modern constitutional law: the right to vote. ${ }^{18}$ The development of this right over the course of the past two centuries converted states that were once operated as private enterprises for the profit of their rulers - whether kings or groups of aristocrats - into the equivalent of consumer cooperatives, in which the tax-paying purchasers of the state's security products exercise control over how the force monopolist wields its power. ${ }^{19}$

The state's coincident disintegration from the means of production has therefore been carried out largely as a matter of policy, rather than law, and the flexibility with which the rule has been applied-recognizing exceptions here and there - is reminiscent of the rule of reason currently applied by the antitrust laws in the United States to govern vertical integration by private monopolists. ${ }^{20}$ According to that rule, vertical integration should be permitted when it makes consumers better off, something that usually turns out to be the case. ${ }^{21}$ Similarly, the democratically-controlled policymakers helming the modern state have tended to approve vertical integration when that would make for better products and hence benefit consumers, but otherwise to leave the provision of goods other than security to private enterprise. ${ }^{22}$ Taken together, these consumer-welfare-based approaches seem to have concluded that there is little a specialist in security has to offer in terms of synergies with most productive activities, and so in general vertical

Forrest Revere Black, Socialism and the Constitution, 28 ILLINOIS L. REV. 313, 317 (1933) (arguing that the U.S. Constitution "has left the door wide open for the adoption of a thorough-going system of Socialism"); U.S. Const. amend. XIII (prohibiting slavery).

${ }^{17}$ See Black, supra note 16, at 317; Woodrow H. Berry \& Suneel Maheshwari, State and Local Taxation in Support of the Governmental Enterprise, Green v. Frazier Revisited, 27 J. STATE TAXATION 29, 38 (2009) (listing "governmental enterprises"); J. Gregory Sidak, Abolishing the Letter-Box Monopoly, 1 CRITERION J. INNOVATION 401, 401-2 (2016) (discussing government support of the Post Office via provision of a statutory letter-box monopoly, among others).

${ }^{18}$ See infra note 120.

${ }^{19}$ See infra Section III.B.2.

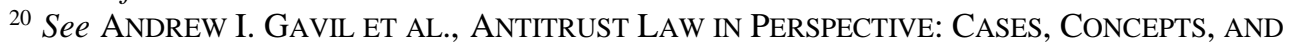
PROBLEMS IN COMPETITION POLICY 870-92, 897-1095 (3d ed. 2017) (tracing the emergence of rule of reason treatment for vertical restraints of all kinds). For more on this connection, see infra Section III.B.2.

${ }^{21}$ See Steven C. Salop, Question: What Is the Real and Proper Antitrust Welfare Standard? Answer: The True Consumer Welfare Standard, 22 LOY. CONSUMER L. REV. 336, 336-38 (2010).

22 See David A Moss, Democracy: A CASe Study 177-243 (2017). 
integration by the state is not welfare enhancing, whereas there are vast synergies between many resources apart from security, with the result that in the realm of private enterprise vertical integration usually makes consumers better off.

Where antitrust and the modern state differ, however, is not in their approaches to vertical integration, but instead in their approaches to price, a divergence that holds an important lesson for current debates over how best to rein in the power of digital platforms. For voters have not just reined in vertical integration by the force monopolist, but also limited the prices the state charges, in the form of taxes, for access to its security product. ${ }^{23}$ In so doing, they put an end to the days of confiscatory taxation on labor manifest in starkest form in the institution of serfdom (a form of taxation that, incidentally, involved extraction of profits in the form of obedience to the commands of the lord, rather than the payment of money). ${ }^{24}$ The modern state's emphasis on fair pricing is far stricter than the modern state's commitment to free enterprise: without exception, no one today is relegated to a subsistence lifestyle by taxation. ${ }^{25}$ Indeed, the tax rate is effectively permanently set at a level equal to the cost of production of the security product, because in the modern state all profits generated by the state must be spent on the people. Paying them to rulers is considered corruption. ${ }^{26}$

There appears to be, in the relatively uncompromising approach of voters to excessive pricing, an intuitive understanding that the charging of low prices is a necessary condition for the elimination of oppression. Even a monopolist that has been disintegrated entirely from downstream marketsthat has turned over the means of production in their entirety to the proletariat - can oppress the public by charging high prices. ${ }^{27}$ Antitrust, by contrast, broadly exempts the charging of high prices by private firms from liability, depriving antitrust of the ability to provide the guarantee against

\footnotetext{
${ }^{23}$ See infra Section III.B.2.

${ }^{24}$ See RoBERT S. DUPLESSIS, TRANSITIONS TO CAPITALISM IN EARLY MODERN EUROPE 2223 (1997) (discussing taxation of serfs including in the form of the requirement that they spend certain days working on the lord's fields); RAOUL CHARLES VAN CAENEGEM, AN HISTORICAL INTRODUCTION TO WESTERN CONSTITUTIONAL LAW 114 (2000) (discussing the principle of English constitutional law that "free people were not taxable without their consent" whereas "serfs . . could be made to pay . . . at the lord's will").

25 See SOI Tax Stats - Individual Statistical Tables by Tax Rate and Income Percentile | Internal Revenue Service, https://www.irs.gov/statistics/soi-tax-stats-individual-statisticaltables-by-tax-rate-and-income-percentile (last visited Sep. 28, 2020) (showing that the average tax rate for the U.S. in 2017 did not exceed $27 \%$ of income).

26 See Peter J. Henning, Public Corruption: A Comparative Analysis of International Corruption Conventions and United States Law, 18 ARIZ. J. INT'L \& COMP. L. 793, 802 (2001).

${ }^{27}$ See HovenKAMP, supra note 3, at 544 (making this point in the context of tie-ins).
} 
oppression that the state provides through the franchise. ${ }^{28}$ The lesson for current debates regarding the tech giants is that Senator Warren's call for a blanket rule prohibiting monopolists from competing on their own platforms is likely to be both ineffective and inefficient. ${ }^{29}$ In prohibiting all vertical integrations, the rule would eliminate some consumer-beneficial integrations, without, however, delivering the guarantee against oppression it seems to seek through the extremity of a blanket ban. For the absence of a rule against excessive pricing in antitrust means that disintegrated firms will remain free to raise prices, not just on consumers but also on the third-party sellers who use the tech giants' platforms and which the rule appears designed in large part to protect. $^{30}$ Prohibiting Amazon from selling products on its own platform will not help third-party sellers if Amazon remains free to tax them at any rate the company wishes. Antitrust policy should take a page from state policy and recognize that price regulation of platform monopolists, combined with a balanced approach to vertical integration that leaves room for integrations that benefit consumers is the only effective regulation of monopoly short of breakup.

\section{THE OVERBREADTH OF ANTITRUST}

Consider the antitrust laws of the United States. ${ }^{31}$ Antitrust law in the United States is concerned with two distinct problems, the acquisition of power, which is regulated by Section 1 of the Sherman Act, and the exercise of power, which is regulated by Section 2 of the Sherman Act. ${ }^{32}$ That gives the antitrust laws the authority to do almost everything that any law can do,

${ }^{28}$ See id. at 356-58.

${ }^{29}$ It is in fact difficult to determine how broad the fumbling definition of "platform" in Senator Warren's proposed rule is meant to be. See Anti-Monopoly and Competition Restoration Act of _ 6(b)(3)(A), 6(b)(4)(D), 6(b)(7)(E) (Draft Copy of SIL19C37) (prohibiting "a person with market power," defined to include firms having in excess of $\$ 40$ billion in revenues, from "serving as both a platform and a merchant that competes with third-party merchants" where " 'platform' means any technology that "provide[s] the main interface between different ... market participants, such as ... providers of . . . services, and goods" and "allows for exchanges of at least some goods [or] services . . . that the technology does not own"). A plausible reading is that it would require vertical disintegration by any large firm from all businesses in relation to which the firm is in some sense essential. See infra Part IV.

${ }^{30}$ See Warren, supra note 14 (arguing that tech platforms "have hurt small businesses").

${ }^{31}$ See 15 U.S.C. $\$ 1$ et seq. (2018).

${ }^{32}$ Section 1 is usually identified as regulating group conduct and Section 2 as regulating single-firm conduct. See 15 U.S.C. $§ 1,2$ (2018) (prohibiting “[e]very contract . . in restraint of trade" and condemning "[e]very person who shall monopolize," respectively); See GAVIL ET AL., supra note 20, at 102. But I will show in this Part how at a deeper level the two statutes instead regulate the acquisition of power and the exercise of power, respectively. 
including all the other laws on the books, for there is little that any law does other than to regulate the acquisition or exercise of power. The only reason for which antitrust's great breadth is not easy to discern is that enforcers of the antitrust laws arbitrarily restrict their attention to a domain involving, usually, the activities of businesses. But antitrust concepts contain no such limitation. ${ }^{33}$ They are, in a sense, radically overbroad, and can only really be understood in relation to the full expanse of human endeavor, not just business activities.

\section{A. Antitrust Regulation of the Acquisition and Exercise of Power}

Consider a natural gas company that owns gas-producing fields, a pipeline, a power plant that serves a particular community, and the transformers and lines that distribute the electricity to the community. ${ }^{34}$ Suppose that this pipeline company does not own all the gas fields at one end

\footnotetext{
33 The language of the Sherman Act does restrict the scope of the antitrust laws to "trade or commerce," a formulation that echoes the language of the Commerce Clause of the U.S. Constitution, which serves as the basis for Congress's authority to pass antitrust laws, and authorizes only the making of laws that regulate interstate "commerce." See 15 U.S.C. $§ 1$ (prohibiting contracts "in restraint of trade or commerce"); 15 U.S.C. $§ 2$ (condemning people who "monopolize any part of . . . trade or commerce"); U.S. Const. art. 1, $\S 8$, cl. 3 (giving Congress power to "regulate commerce with foreign nations, and among the several states"); AREEDA \& HOVENKAMP, supra note 3, TII 260b, 260c. But the courts have not hesitated to read the term "commerce" to apply to any sort of human activity at all when such an expansive definition has suited their purposes. See Wickard v. Filburn, 317 U.S. 111, 11829 (Supreme Court 1942) (holding that Congress can prohibit the growing of wheat for personal consumption under the powers provided by the Commerce Clause).

That the foundation of the limitation of the antitrust laws to business activities lies in mere custom is evident in two commentators' defense of the limitation. They write that the limitation "is relatively clear from the Sherman Act's legislative history. When speaking of the types of practices that would offend the proposed statute, without exception the participants in the debate referred to the activities of private firms." AREEDA \& HOVENKAMP, supra note 3, II 260c. They continue, arguing that it is not antitrust's object to intervene in people's noncommercial affairs. If Congress has intended the antitrust laws to regulate political markets, charity, or other noncommercial affairs, it would not have limited its statute to common law terms describing commercial relations, such as "contract," "combination," or "conspiracy;" or to economic terms such as "monopoly" or "effect on competition."
}

Id. Thus it is the customary use of these terms to describe business contexts, and not the conceptual apparatus of the antitrust laws themselves, that accounts for the practice of applying them only in business contexts.

${ }^{34}$ Richard Vietor's description of the natural gas industry during the height of regulation in the United States is the inspiration for this example. See RICHARD H. K VIETOR, CONTRIVED COMPETITION: REGULATION AND DEREGULATION IN AMERICA 102, 154 (1996). 
of its pipeline, just some of them, and does not own all the power plants at the other end of its pipeline, just some of them, but that the company does own the only pipeline capable of connecting any gas-producing field, whether owned by the company or not, to any power plant, whether owned by the company or not. Antitrust is concerned with two questions in this and every case. What amount of control should this or any single company be allowed have over the pipeline? And if a company has enough control to wield power over those who need access to the pipeline, what are acceptable exercises of that power and what are not? It may come as a surprise to the reader that antitrust asks such general questions. But it really does, although not precisely in these terms.

For example, Section 1 of the Sherman Act is concerned with "combination[s] . . . in restraint of trade," which the courts understand to mean attempts by firms to cooperate with each other or to go further and combine their operations through merger or acquisition. ${ }^{35}$ Combinations, from price-fixing conspiracies to mergers, concern antitrust because they can centralize control over some input that is essential to a particular production process in the hands of a single self-interested intelligence, whether a group of firms operating in tandem or a single dominating human owner. And from such centralization of control over an essential thing comes power. In merger cases, for example, the courts speak always about the tendency of the merger to lead directly to market power - the so-called "merger to monopoly"-or to lead to centralization of control over some input in such a small number of hands that those hands are likely to cooperate to exercise power jointly, completing the centralization process. ${ }^{36}$ In cases involving combinations between firms at different levels of a supply chain-power companies and pipeline owners, for example - the concern is similarly that the combination will allow a firm operating at one point in the supply chain to reach up or down the chain to centralize control over resources at a different level of the supply chain, a process known in this context as "foreclosure." 37 And the courts see price-fixing contracts between competitors as so obviously motivated by a desire to pool control over some essential input in the service

${ }^{35}$ See 15 U.S.C. $\$ 1$ (2018); AREEDA \& HOVENKAMP, supra note 3, III 902a, 1400a. Section 7 of the Clayton Act imposes additional and somewhat more expansive limits on mergers. See 15 U.S.C. § 18 (2018); Id. III 902b, 902c.

${ }^{36}$ See HoVENKAMP, supra note 3, at 649 ("The anticompetitive consequences of mergers can be grouped under two general headings. Under the first comes mergers that permit the postmerger firm to make a significant price increase, while other firms in the market either keep their price the same or take a much small increase. The second justification . . . includes mergers that facilitate collusion or other forms of coordinated interaction, thus permitting all firms in the market to increase their price.").

${ }^{37}$ See id. at 502-3, 547, 564-65 (discussing foreclosure in these contexts). 
of exercising power over others that the law bans such agreements on their face without even bothering to ascertain whether power has in fact been achieved through them. ${ }^{38}$ The question that Section 1 poses for our energy company is whether the company's control over that pipeline, which is essential to the distribution of gas-produced power to the community, should be allowed to stand. If the answer is no, and that control has been achieved through contracts, then Section 1 would prohibit compliance with the contracts. ${ }^{39}$ If the answer is no, and that control has been achieved through the exercise of property rights, then Section 1 would unwind the acquisition or merger that brought those property rights to the firm. ${ }^{40}$

If Section 1 of the Sherman Act is concerned with power, achieved, as all power is achieved, through centralized control over some essential resource, whether talent, oil and gas, production facilities, roads, sales or distribution lists, personal experience, or something else, Section 2 of the Sherman Act is concerned with permissible exercises of that power. ${ }^{41}$ This is perhaps harder

${ }^{38}$ See id. at 209, 329-335 (stating that "[b]y design, a cartel behaves like a monopolist ....." and describing the rationale for antitrust's rule that price fixing is illegal per se and therefore requires no proof of market power). The courts treat agreements that are not on their face directed toward the fixing of prices or output with somewhat more care, but they will condemn them if the centralization of power they make possible is unnecessary or has no offsetting benefits. See id. at 247-54.

The essential unity of vertical and horizontal collusion between competitors as both having the same goal of power acquisition is somewhat elliptically evident in the observation of Steve Salop and Thomas Krattenmaker that foreclosing supply and inducing collusion are the two principal ways in which firms monopolize markets. See Thomas G. Krattenmaker \& Steven C. Salop, Anticompetitive Exclusion: Raising Rivals' Costs To Achieve Power over Price, 96 YALE L.J. 209, 236-42 (1986). What they fail to appreciate is the implication that these two quintessentially conspiratorial activities show that antitrust's rules against collusion, rather than antitrust's rules against monopolization, lie at the heart of antitrust's opposition to the acquisition of power.

39 See Ramsi A. Woodcock, Inconsistency in Antitrust, 68 U. MIAMI L. REV. 105, 120-25 (2013) (discussing contract-based centralization of control under the unfortunate label of "contract-based exclusion"); See A. Douglas Melamed, Afterword: The Purposes of Antitrust Remedies Symposium: Remedies for Dominant Firm Misconduct, 76 ANTITRUST L.J. 359, 362-63 (2009-2010) (discussing the remedy of "terminating [the] unlawful conduct") .

40 See Woodcock, supra note 39, at 120-25 (discussing property-based centralization of control under the unfortunate label of "property-based exclusion"); Timothy J. Muris \& Jonathan E. Nuechterlein, First Principles for Review of Long-Consummated Mergers, 5 CRITERION J. INNOVATION 29, 34-48 (2020) (discussing the unwinding of "longconsummated" mergers under the antitrust laws).

41 See 15 U.S.C. $\S 2$ (2018). For talent as an essential input, see Oliver E. Williamson, Dominant Firms and the Monopoly Problem: Market Failure Considerations, 85 HARV. L. REV. 1512, 1516-17 (1972).. For experience as an essential input, see Harold Demsetz, Industry Structure, Market Rivalry, and Public Policy, 16 J.L. \& ECON. 1, 2 (1973). For lists as valuable inputs, see AREEDA \& HOVENKAMP, supra note 3, II 2213c (customer lists as important joint venture assets). For roads as essential inputs, see Robert Pitofsky et al., The 
to see from the language of the act than is the relationship of Section 1 to the problem of the acquisition of power. For Section 2 condemns only those who "monopolize," and that almost seems to mean the act of acquiring power, the same subject matter as Section $1 .{ }^{42}$

The courts were themselves confused about this point for a long time. But starting in the 1970s, they settled on the view that a violation of Section 2 requires evidence of what has come to be called "exclusionary conduct." 43 That too suggests something like the centralization of control over resources, through the exclusion of others from access to them, and in fact this suggestion confused this Article's author for many years. ${ }^{44}$ But in practice, the courts have always used Section 2 not to deny firms control over resources, but to prevent firms from wielding preexisting control in ways that the courts deem overbearing. Thus at various times, the courts have relied upon Section 2 to prohibit the charging of below-cost prices, which may be understood to amount to abuse of an advantage in access to cash, tying, which is just the use of control over an essential resource to induce purchase of a second product, or the refusal of a firm to supply an essential resource to a competitor. ${ }^{45}$ In all of these cases the court acts to limit the ability of a firm to exercise power over a resource that the firm controls.

These monopolization offenses do not challenge the right of the firm to control the resource in question, whether through direct ownership, contractual relationships, or indeed even informal agreements. There is no claim that the legal rules that support the firm's control over the resourcethe property law rules that give the firm title to essential inputs or the contracts that compel those with control over essential inputs to comply with

Essential Facilities Doctrine under U.S. Antitrust Law, 70 ANTITRUST L.J. 443, 446 (2002) (discussing the Terminal Railroad decision). For production facilities $I d$. at 447 (discussing cases requiring that sports teams be provided access to stadiums, which of course are game production facilities).

4215 U.S.C. $\S 2$ (2018) ("Every person who shall monopolize . . . shall be deemed guilty of a felony .....").

43 See Elyse Dorsey \& Jonathan M. Jacobson, Exclusionary Conduct in Antitrust, 89 ST. JOHN'S L. REV. 101, 104, 114-15, 117-19 (2015) (observing that the first "truly significant" monopolization case was not decided until 1945, when the court condemned all monopolies that are not "thrust upon" the monopolist, that the courts started imposing limitations on the sort of conduct that would count as monopolization starting in the 1970s, and that only in the 1990s did scholars start to give content to the distinction between good and bad forms of monopolizing conduct); GAVIL ET AL., supra note 20, at 439-45 (discussing "exclusionary conduct").

${ }^{44}$ See Woodcock, supra note 39, at 143-45 (arguing that monopolization, like cartelization, centralizes control over inputs).

${ }^{45}$ See HovenKAMP, supra note 3, at 376, 543-46 (listing examples of exclusionary conduct and describing the monopoly "leverage" theory of tying). 
the firm's wishes - are invalid simply in virtue of the monopoly power to which they give rise. ${ }^{46}$ If that were the case, then Section 2 would prohibit monopoly as such, whereas the courts are clear that bad conductmisleadingly called "exclusionary" conduct - and not just monopoly power, is required for liability under Section $2 .{ }^{47}$ Indeed, if Section 2 were to prohibit monopoly as such, then it would impinge on the domain of Section 1, which is devoted to preventing the use of contract (through anti-collusion rules) and property law (through anti-merger rules) to centralize control over inputs and therefore to create monopolies. ${ }^{48}$ Instead, these offenses challenge the manner in which the firm exercises its control over essential resources. ${ }^{49} \mathrm{It}$ is not the mere fact that the monopolist owns an essential input, or has tied up an essential input through exclusive dealing contracts, that gives rise to liability, but the fact that the firm exercises its control over the input to deny access to the input to competitors, or to insist that consumers who want the input also purchase other products from the firm. ${ }^{50}$

The essential difference between Section 2's focus on conduct and Section 1's focus on power can be told from the universal requirement in all Section 2 cases that the plaintiff prove that the defendant has "monopoly power." 51 That requirement is separate from the requirement of proof of exclusionary conduct, and effectively requires that a firm have centralized control over an essential input as a prerequisite for liability. The two requirements - monopoly power plus exclusionary conduct - work together to establish that only a firm that has centralized control over an essential input and has gone on to exploit that control in some way can be held liable for monopolization under Section 2. It is a quirk of the antitrust laws that the monopoly power requirement applies to the downstream market into which the firm sells its products, rather than directly to the market for the input that serves as the basis of the firm's power. ${ }^{52}$ But a firm cannot acquire monopoly

\footnotetext{
${ }^{46}$ See Woodcock, supra note 39, at 120-25 (arguing that firms use property law and contract law to centralize control over inputs).

47 See HovenKamp, supra note 3, at 356 (stating that "monopolization still requires monopoly power plus some form of anticompetitive conduct. The sale of output at a monopoly price is itself not sufficient to brand someone an unlawful monopolist.").

${ }^{48}$ See Woodcock, supra note 39, at 120-25.

${ }^{49}$ See HovenKAMP, supra note 3, at 346. For more on the kinds of exercises of power that antitrust tends to prohibit, see infra Section III.B.1.

${ }^{50}$ See id. at 381-82, 543-46 (discussing refusals to deal and the leverage theory of tying).

51 See id. at 103-4.

${ }^{52}$ See AREEDA \& HOVENKAMP, supra note 3, II 570a (stating that market definition is aimed at "appraising the competitive significance of firms in the same market," implying that a test of monopoly power that focuses on control over an input in a market in which a firm's downstream competitors do not compete would not be appropriate); Ramsi A. Woodcock, Digital Monopoly without Regret, CONCURRENCES, 2020, at 53, 56 ("The monopolist must
} 
power in the market into which the firm sells its products unless the firm controls some upstream resource that competitors need in order to compete in the downstream market. ${ }^{53}$ So the monopoly power requirement nevertheless provides useful information about the essentiality of the resource controlled by the firm.

Only once the existence of monopoly power in the downstream marketand, by extension, control over an essential input-is demonstrated does Section 2 kick in to regulate how that power is exercised. ${ }^{54}$ In our example, the power company owns inputs at each level of the supply chain connecting gas to electric power consumers. The company owns gas-producing fields that may allow the company to exercise power downstream in the pipeline market. The company owns pipelines that allow it to exercise control downstream in the power generation market. The company owns power plants that may allow the company to exercise power downstream in the market for power distribution. And the company owns power distribution lines that may allow the company to exercise power downstream in the retail electricity market. If the company's control of resources at any level of the supply chain gives the firm power over prices in any downstream market, Section 2 can step in to regulate the company's exercise of control over those resources. ${ }^{55}$ Antitrust can force the company to sell gas to competitors wishing to enter the pipeline market, for example, or force the company to use its pipeline to supply gas to competing power generators, or force the company to transmit the electricity of competing power generators to consumers. ${ }^{56}$

\section{B. Antitrust's Definition of Market Power Is Not Limited to Business Conduct}

The power in which antitrust has traditionally been interested is what antitrust calls "market power," meaning the power of a firm to raise the prices

\footnotetext{
abuse its own markets.").

${ }^{53}$ See Woodcock, supra note 39, at 136-41.

54 See HovenKAMP, supra note 3, at 352-54 (discussing “monopolization's market power requirement").

${ }^{55}$ So, for example, if the company's control over power distribution lines enables to company to drive competitors from the retail electricity market, then antitrust enforcers can step in to force the company to allow rivals to send power to their own retail customers using the company's distribution lines. See id. at 387 (discussing the Otter Tail Power case in which the Supreme Court ordered a power company to open its distribution lines to a rival). But, importantly, not every exercise of power violates Section 2. See infra Section III.B.1.

${ }^{56}$ See id. at 381-88 (discussing refusal to deal and the remedy of forced sharing).
} 
it charges to customers without driving them away. ${ }^{57}$ The greater the firm's control over some essential input into the production process, the less able customers will be to obtain the product from rivals if they dislike the prices charged to them, and therefore the greater the ability of the firm to raise prices profitably. ${ }^{58}$ Although the name "market power" suggests that the antitrust laws are limited to business contexts, and the application of the laws has generally followed that suggestion, in point of fact the concept of market power applies quite broadly to all power, even under antitrust's own prevailing rules. ${ }^{59}$ For antitrust law has long recognized that price need not be denominated in dollars and cents. ${ }^{60}$ Price can be anything of value. Thus a firm, like Facebook, that extracts data from a user in exchange for the provision of social media services, charges data-denominated prices. ${ }^{61}$ Firms that extract free services, or goods, as opposed to cash, from customers can similarly be understood to be charging a price for their services for purposes of establishing the existence of market power. ${ }^{62}$ It follows that under the

${ }^{57}$ See John B. Kirkwood, Market Power and Antitrust Enforcement, 98 B.U. L. REV. 1169, 1172 (2018).

${ }^{58}$ See Woodcock, supra note 39, at 136-41; Woodcock, supra note 52, at 55 ("It is obvious enough that a firm can degrade competitors' products, without improving its own, only by depriving competitors of inputs they need but which the firm does not need for its own products.").

${ }^{59}$ For more on the customary application of the antitrust laws to business contexts, see supra note 33.

${ }^{60}$ See supra text and references contained in note 6.

61 See Elias Deutscher, How to Measure Privacy-Related Consumer Harm in Merger Analysis? A Critical Reassessment of the EU Commission's Merger Control in Data-Driven Markets, No. ID 3075200, 15 (2017) (“[O]ne could frame changes in a firm's privacy policies that require disclosure of more comprehensive user information as 'price increases'.").

62 Indeed, that is the basis upon which plaintiffs are able to prove market power in monopsony cases under the antitrust laws. See generally AREEDA \& HOVENKAMP, supra note 3, II 575 (discussing the measurement of monopsony power); Roger D. Blair \& Jeffrey L. Harrison, Antitrust Policy and Monopsony, 76 CoRnell L. REV. 297, 310-21 (19901991) (reviewing cases that show that antitrust condemns exercises of monopsony power as well as exercises of monopoly power). The inverse of a monopolist, a monopsonist uses centralization of control over a downstream input to acquire power in an upstream market. It is commonly said that the monopsonist uses that upstream power to dictate low purchase prices to the suppliers from which the monopsonist sources its inputs, pocketing the savings. See HovenKAMP, supra note 3, at 17-20 (outlining the economics of monopsony). But it may be said with equal accuracy that the input suppliers are actually buyers of the monopsonist's cash, and that the suppliers pay for that cash in the form of the goods or services that the suppliers provides to the monopsonist. The only difference between the monopolist and the monopsonist from this perspective is that the monopolist charges a dollardenominated price for its product whereas the monopolist charges a good- or servicedenominated price. The monopsonist's power is then identical to the power of the monopolist, in the sense that it is expressed in an ability profitably to raise price, the only 
antitrust laws power is defined as the ability of a firm profitably to extract anything of value from others.

Profitability in the economic sense rests on the balancing of two opposing effects associated with a firm's demand of more value from customers. Some refuse to pay the higher price. ${ }^{63}$ Others pay it. ${ }^{64}$ If the benefits to the firm from charging more to those who pay more exceed the losses to the firm from losing the business of those who refuse to pay more, then the increase in price is profitable. ${ }^{65}$ Because antitrust does not insist on a money price, the shorthand that power is shown by a profitable increase in price expresses the broader rule that power exists where a firm is able to benefit from demanding more from others.

Outside of antitrust and economics, it is not common to consider the tradeoff between benefit and demanding more from others that is associated with the exercise of power. But that is not because the tradeoff is not a part of all exercises of power. The power of a leader means that when the leader demands obedience, the leader's subjects respond. The leader may demand that his subjects risk their lives on the field of battle. Power means that the leader's subjects will in fact go out and do that. But it is commonplace to recognized that there is always, or often, dissent, even to the demands of the most powerful leaders. ${ }^{66}$ Power, they say, creates resistance. ${ }^{67}$ There is

difference being that for the monopsonist the price that the monopsonist can profitably raise is denominated in units of the good or service provided to the monopsonist, rather than in dollars. When the monopsonist uses power to artificially depress the price the monopsonist pays suppliers, the monopsonist is, equivalently, artificially inflating the number of units of the supply good or service that the monopsonist is charging suppliers per unit of cash paid by the monopsonist to them. The monopsonist is profitably raising a non-dollar-denominated price. It follows immediately that "price" in the definition of market power as the power profitably to raise price can be anything of value, not just dollars and cents. Commentators have not, unfortunately, always seemed entirely aware of this implication of monopsony power. See Herbert Hovenkamp, Whatever Did Happen to the Antitrust Movement, 94 NotRE DAME L. REV. 583, 622 (2018-2019) (trying to account for the peculiarity of monopsony power that it leads to lower supply prices by arguing that "[f]ocusing on output is usually better than focusing on price ... in cases involving monopsony").

Some explanation is required for the claim above that a monopsonist uses centralization of control over a downstream input to acquire power in an upstream market. Downstream input control translates into upstream power when the upstream suppliers sell inputs that are only valuable within supply chains to which the downstream inputs belong. In that case, the upstream suppliers cannot sell their inputs into alternative supply chains and so are forced to accept the terms dictated by the firm that controls the supply chain downstream.

${ }^{63}$ See HovenKAMP, supra note 3, at 113.

${ }^{64} \mathrm{See}$ id.

${ }^{65}$ See id.

66 See, e.g., ANDREW HSIAO \& AUdREA LiM, THE Verso Book OF Dissent: REVOLUTIONARY WORDS FROM THREE MILLENNIA OF REBELLION AND RESISTANCE (2020).

${ }^{67}$ See 1 Michel Foucault, The History OF SEXUAlity 95-96 (Robert Hurley trans., 1990) 
always a dodger of the draft. A shirker of duties. A traitor. These dissenters are the customers, in the economic model of market power, who refuse to pay the higher price when the firm demands a higher price. ${ }^{6}$ Every leader must consider whether enough of his people will respect a demand to make the demand worthwhile. ${ }^{69}$ If the leader's power is limited, then so many people will refuse to obey that the leader may be made worse off. ${ }^{70}$ The benefit of the compliance of a handful of followers will be more than offset by the catastrophic collapse of obedience by the rest of the group. ${ }^{71}$ The economic model of profitability, with its emphasis on the balancing of the benefits of compliance with the higher price against the losses associated with pricing some customers out of the market, merely reproduces in the language of business and economics a fundamental tradeoff with which all exercises of power must contend. ${ }^{72}$ Antitrust's definition of market power as the ability profitably to extract anything of value from others therefore reduces to an intuitive universal definition of power: the ability to induce others to comply with commands. ${ }^{73}$

Any order to others must be understood to extract something of value from those receiving the order and to confer that value on the one giving the order, otherwise no one would issue orders. Leaders command some to die in battle. Others to work the fields. Others to produce art. Each of these extracts value in the form of labor, as well as all of the other things that the subject must provide in order to comply, including arms if the order is to make war, seed and tools if the order is to farm, and so on. But it might at first appear that those who obey orders get nothing in return. That would be an important substantive difference between the broader world of power and the sorts of power defined by the antitrust laws. In the business world, the monopoly sells at a high price, but cannot simply extract the high price without actually providing a good or service in exchange.

This appearance is deceiving, however. Power is always an exchange, for

("Where there is power, there is resistance[.]").

${ }^{68}$ See HOVENKAMP, supra note 3, at 113.

${ }^{69}$ See 2 MAX WEBER, ECONOMY AND SOCIETY: AN OUTLINE OF INTERPRETIVE SOCIOLOGY 1112-13 (1968) (stating, of the charismatic leader, that "[i]f those to whom he feels sent do not recognize him, his claim collapses; if they recognize it, he is their master as long as he 'proves' himself').

${ }^{70}$ See id.

${ }^{71}$ See id.

${ }^{72}$ See HovENKAMP, supra note 3, at 113 (describing the economic model of the profitability of price increases).

73 See 1 MAX Weber, ECONOMY AND SOCIETy: An OUTLINE OF INTERPRETIVE SOCIOLOGY 53 (1968) (“"Power' is the probability that one actor within a social relationship will be in a position to carry out his own will despite resistance ... . 'Domination' is the probability that a command with a given specific content will be obeyed by a given group of persons."). 
the actions of others can never be compelled unless the actors expect something in return. That is not always evident outside of the business context because in business the customer usually obtains through the exchange something that makes the customer better off relative to a world in which the firm were not to exist. The power company's customers obtain electricity in exchange for their dollars, and the access to electricity makes the customer better off than the customer would have been absent the transaction, rendering the quid pro quo obvious. Outside of the business context, by contrast, the thing the follower often obtains in exchange for obedience is deliverance from punishment. We are not accustomed to treating deliverance from punishment as an economic object, but it most certain is such. ${ }^{74}$ Security, whether from the leader or anyone else, may well be the most important commodity for which anyone can trade.

The fact that the leader takes security from the follower - threatening a beating, for example, if the follower does not supply obedience-before selling security back to the follower in exchange for that obedience, does not make the exchange between leader and follower any less an exchange. Indeed, the view that security is taken and then sold back merely reflects a certain social-contractarian naivete. ${ }^{75} \mathrm{We}$ have a tendency to think of our natural state as one of freedom from violence, hence the appeal of the view that government is a social contract to which natively-free people submit. ${ }^{76}$ But if instead our natural state is to be subject to the violence of a leader, then the leader does not take security and then sell it back to followers in exchange for obedience, but rather supplies a genuine good-security from himselfthat the follower would not otherwise have. The fact that the leader could voluntarily choose to provide the security without demanding obedience as payment has no more bearing on the question whether there is a genuine exchange when followers obey to avoid punishment than the fact that the power company could choose to distribute its electricity for free instead of demanding payment in exchange for supplying it has bearing on the question whether the purchase of electricity counts as an exchange. ${ }^{77}$

\footnotetext{
${ }^{74}$ See Gerrit De Geest \& Giuseppe Dari-Mattiacci, The Rise of Carrots and the Decline of Sticks, 80 U. CHI. L. REV. 341, 347 (2013) ("Carrots and sticks are prima facie equivalent because any behavioral change induced by promising compliers a $\$ 100$ reward can also be obtained by threatening violators with a $\$ 100$ punishment.”).

75 See, e.g., Johannes Jahn \& Rolf Brühl, How Friedman's View on Individual Freedom Relates to Stakeholder Theory and Social Contract Theory, 153 J. BUS. ETHICS 41, 48 (2018) ("When single individuals disagree with the norms of their community, they have the right to leave it.").

${ }^{76}$ See id.

77 The notion that obedience is not an exchange because one has a right to live free from violence in the first place is ultimately an argument about the proper distribution of wealth,
} 
So the basic model of power as the ability of a seller profitably to raise price holds generally for all power. ${ }^{78}$ All power, even the power of a leader to demand the obedience of his subjects, has this character of an unequal exchange. Because this model of power holds universally, and it is precisely the model of power that antitrust embraces, albeit always misleadingly expressed in the language of business and economics, antitrust applies universally to all power. All power relationships may be conceptualized as market power relationships, thereby triggering antitrust's concerns regarding whether the centralization of control over an essential input that undergirds that power is legitimate (the subject of Sherman Act Section 1) and, if so, whether the exercise of that power is legitimate as well (the subject of Sherman Act Section 2).

a point that follows directly from Ronald Coase's work. Coase made clear that whether a firm has a right to pollute the environment determines the endowment of the polluter. See R. H. Coase, The Problem of Social Cost, 3 J. L. \& ECON. 1, 6-8 (1960) (considering the question in the context of the externalities inflicted by cattle grazing on crop farmers). If the polluter has such a right, then the polluter has something of value that the polluter can exchange for cash or other compensation from victims, who wish to acquire pollution rights from polluters in order to shut pollution down. See id. If the polluter does not have the right to pollute, then the polluter does not have a valuable right available to trade, and must instead pay cash to victims to obtain from them the right to pollute, an exchange into which victims will not enter unless the price is right. See id. By the same token, the leader's ability to inflict violence on the disobedient follower is the leader's endowment. It represents a particular distribution of wealth. This endowment gives the leader something to trade with the follower in exchange for obedience: the leader sells respite from his violence to the follower, who pays for it in obedience. The view that this is not a real exchange because the leader ought not engage in violence to begin with is tantamount to the view that the leader should not be endowed with the ability to inflict violence on others. That view therefore does not really question the existence of an exchange-when followers buy safety they get something real in exchange for their obedience-but rather attacks the distribution of a valuable right to violence to the leader, one that the leader then uses as the basis for trade with others.

It should be noted here that whereas Coasian analysis is usually framed in terms of the allocation of rights (e.g., to pollute), there are no rights at issue in the leadership context to which the analysis is applied here. See id. at 44 (urging that legal rights should be treated as commodities). The leader's power to engage in violence derives from personal physical strength, Weberian charisma, and the like, not law. See 2 WEBER, supra note 69, at 1112-13 (discussing charismatic leadership). Coasian references to the proper allocation of legal rights presuppose that there is some third-party separate from polluter and victim, one that is able to use its own threats to compel obedience with legal rules and therefore has the power to allocate legal rights. That power is of course called "government." But the source of government's power to impose law on private parties ultimately can only lie in physical strength, charisma, and whatever else gives the government a monopoly on violence.

78 See Duncan Kennedy, The Stakes of Law, or Hale and Foucault Transformative Discourses in Postmodern Social Cultural and Legal Theory, 15 LEGAL STUD. F. 327, 35556 (1991) (criticizing Foucault for failing to perceive "the intersection of disciplinary with market power"). 


\section{Antitrust's Rules Regarding the Exercise of Power Are Not Limited to Business Conduct}

Antitrust's market power requirement measures the extent to which a firm has centralized control over an input. ${ }^{79}$ The generality of the definition of market power employed by antitrust suggests that all centralizations of control, whether in relation to things like pipelines that are normally considered relevant to commerce, or in relation to things like violence that are normally considered a matter of politics, are covered by the antitrust laws. ${ }^{80}$ The implication is that enforcers can use Section 1 of the Sherman Act to block or unwind centralizations of control that create power of any kind in society, whether that power is typically understood to be economic or political in nature. But blocking and unwinding centralizations of control is only one function of law, because power is pervasive and often necessary. ${ }^{81}$ There can be no government, for example, without a power capable of coercing just behavior by members of the public. ${ }^{82}$ The other major activity of the law is therefore the regulation of the exploitation of power, to ensure the wise use of power. ${ }^{83}$ Section 2 of the Sherman Act, which addresses the exercise of power, is, like antitrust's market power concept, so broad that it would allow antitrust to substitute for virtually any other legal regime that regulates the exercise of power, including all of constitutional law.

The argument for Section 2's breadth is that the courts seem comfortable defining and redefining the set of permissible exercises of power, suggesting that no real limitations on Section 2's authority to regulate power exists. Courts and commentators have always recognized that the antitrust laws in the United States are constitutional in the sense that they create a great and inchoate authority, and common-law-like in the sense that the courts are free

\footnotetext{
${ }^{79}$ See supra Section II.A.

${ }^{80}$ See supra Section II.B; $c f$. AREEDA \& HovenKAMP, supra note 3, II 260c (stating that "antitrust not intended to correct political markets").

${ }^{81}$ See Kennedy, supra note 78, at 351-52 (observing that both Robert Hale and Michel Foucault recognize that power is pervasive in social life, that "owners coerce workers . . . but workers [also] coerce owners"); JOSEPH A. SCHUMPETER, CAPITALISM, SOCIALISM, AND DEMOCRACY 95 (1994) (observing that market power sometimes makes "fortresses out of what otherwise might be centers of devastation" due to ruinous competition).

${ }^{82}$ In theory, of course, the public, and indeed every member thereof, might submit to leadership that it believes to be just, without any need for the application of coercion. See JosePh NeEDHAM, THE GRAND TITRATION: SCIENCE AND SOCIETY IN EAST AND WeSt 312 (1969) ("Confucius ... said that if the people were given laws and levelled by punishments, they would try to avoid the punishments but have no sense of shame; but that if they were 'led by virtue' they would spontaneously avoid disputes and crimes."). But that is not the system found in most countries.

${ }^{83}$ For more on how the law regulates exercises of power, see infra Section II.D.
} 
to wield that authority as they see fit, changing their approach over time as their understanding of the world and the needs of the people develops. And the courts have used that authority radically to alter the content of permissible exercises of power over time. ${ }^{84}$ Before the Chicago revolution of the 1970s, the courts condemned a wide range of conduct to the end of protecting a wide range of societal values, from the "liberty of the entrepreneur" to "the promotion of small business enterprise." ${ }^{\prime \prime}$ Under this approach it was illegal, for example, for a firm having monopoly power to increase supply to meet demand, because that would deny a business opportunity to a potential competitor. ${ }^{86}$ With the Chicago revolution, the courts discarded this approach and adopted a radically different one, without Congress enacting any change to the language of Section $2 .{ }^{87}$ After Chicago, the courts discarded all of the antitrust policies to which they had previously adhered and embraced a single one: the protection of consumer welfare in the economic sense. ${ }^{88}$ The rules the courts applied to limit the exercise of power changed along with this change in values. ${ }^{89}$ Increasing supply to meet demand stopped being an antitrust violation, as did a prohibition on below-cost pricing (absence a dangerous probability of recoupment), and a rule against denials of access to essential facilities. ${ }^{90}$ Indeed, the courts abandoned the entire concept of rulebased governance of firm conduct, embracing the case-by-case approach to

\footnotetext{
${ }^{84}$ See William F. Baxter, Separation of Powers, Prosecutorial Discretion, and the Common Law Nature of Antitrust Law, 60 TEX. L. REV. 661, 663 (1981) ("The antitrust laws were written with awareness of the diversity of business conduct and with the knowledge that the detailed statutes which would prohibit socially undesirable conduct would lack the flexibility needed to encourage [and at times even permit] desirable conduct. To provide this flexibility, Congress adopted what is in essence enabling legislation that has permitted a common-law refinement of antitrust law through an evolution guided by only the most general statutory directions."); N. Pac. Ry. Co. v. United States, 356 U.S. 1, 4 (Supreme Court 1958) (describing the antitrust laws as "a comprehensive charter of economic liberty").

${ }^{85}$ See Kenneth G. Elzinga, Goals of Antitrust: Other Than Competition and Efficiency, What Else Counts, 125 U. PA. L. REV. 1191, 1194-1202 (1977) (listing "redistribution of income," "promotion of small business enterprise," "promotion of the liberty of the entrepreneur," and "neutral treatment of minorities" as examples of goals pursued by antitrust during this period).

${ }^{86}$ See Dorsey \& Jacobson, supra note 43, at 104-5 (discussing the "thrust upon" standard created by the Alcoa case).

${ }^{87}$ See GAVIL ET AL., supra note 20, at 699 (suggesting that a similar change in merger policy, without Congressional action or even a change in Supreme Court caselaw might amount to "civil disobedience" by lower courts).

${ }^{88}$ See Dorsey \& Jacobson, supra note 43, at 108-17.

${ }^{89}$ See id.

${ }^{90}$ See id.; HovenKAMP, supra note 3, at 401-2 (observing that the Supreme Court has placed "severe limitations" on essential facilities claims in recent years).
} 
adjudication known as the "rule of reason" in antitrust. ${ }^{91}$ Under this rule, courts do not regulate particular practices at all, but instead consider the effect of challenged practices on consumers in each case, much the way a sovereign makes decisions on a case by case basis with the good of the nation in mind. ${ }^{92}$

Against this backdrop, it is hard to see how the courts could ever reject a particular limitation on the exercise of power as inconsistent with the antitrust laws, as opposed to inconsistent with whatever goal for the antitrust laws the courts happen to favor in the moment. At one time, competition seemed to be a value from which the courts could not depart by too much in interpreting the antitrust laws. ${ }^{93}$ But the heart of the Chicago revolution in antitrust was the argument that the antitrust laws should not adhere too literally to the goal of promoting competition, because sometimes a firm with market power is better able to satisfy consumers than firms operating in a competitive market would be. ${ }^{94}$ If the courts were able to cast aside competition for its own sake as the ultimate policy of the antitrust laws, they can embrace any policy for those laws. It follows that antitrust could, for example, impose the Bill of Rights contained in the U.S. Constitution on a particular monopolist. ${ }^{95}$ Or antitrust could impose the language contained in the European Convention

\footnotetext{
${ }^{91}$ See National Soc. of Professional Engineers v. United States, 435 U.S. 679, 692 (Supreme Court 1978) (distinguishing the analysis "of the facts peculiar to the business" taken by courts in "rule of reason" cases from the rules of per se illegality applied in other cases); Timothy J. Muris, The New Rule of Reason, 57 ANTITRUST L.J. 859, 859 (1988) (arguing that virtually all of antitrust law is now subject to the rule of reason).

${ }^{92}$ See Maurice E. Stucke, Does the Rule of Reason Violate the Rule of Law?, 42 U.S. DAVIS L. REV. 1379 (2009) (arguing that the rule of reason in antitrust is not a "directive defined ex ante" and therefore is not lawlike in character); HovENKAMP, supra note 3, at 358-59 (discussing the harm to consumer welfare necessary to establish bad conduct for purposes of Section 2).

${ }^{93}$ See N. Pac. Ry. Co. v. United States, 356 U.S. 1, 4 (Supreme Court 1958) (stating that "the policy unequivocally laid down by the [Sherman] Act is competition").

${ }^{94}$ See Dorsey \& Jacobson, supra note 43, at 115-16 (showing how the Chicago School altered antitrust law based on the premise that "protecting competition is not an end unto itself, but merely a means for preserving and enhancing consumer welfare and the competitive process"); Frank H. Easterbrook, Workable Antitrust Policy, 84 MicH. L. REV. 1696, 1700 (1986) (describing as one of the tenets of the Chicago School of antitrust that "No antitrust policy should be based on a belief that atomistic competition is better than some blend of cooperation and competition").

${ }^{95}$ See U.S. Const. amends. 1-10 (prohibiting the exercise of governmental power to abridge the freedoms to speak, assemble, practice religion, petition the government, bear arms, avoid unreasonable searches and seizures, be subject to criminal prosecution without certain procedural protections, and so on). If antitrust were to impose the Bill of Rights on a private firm, the result would be that the firm could not limit the freedom of expression of its employees on pain of firing, or the freedom of expression of its customers on pain of being denied access to the firm's products, for example.
} 
on Human Rights. ${ }^{96}$ Commanding firms to exercise power in a manner consistent with human rights likely would not advance antitrust's current policy of promoting consumer welfare-employees busy protesting management are unlikely to be able to deliver the highest quality products to consumers at the lowest possible prices - but it would advance a policy of promoting democracy, one that seems to have played a partial role in preChicago decisionmaking in antitrust and which antitrust could choose to embrace if it wished. ${ }^{97}$

Taking the breadth of antitrust's authority to regulate the acquisition of power together with the breadth of antitrust's authority to regulate the exercise of power, it becomes clear that the antitrust laws are not so much an area of law as the concept of law itself, a legal regime charged with doing what law does at the greatest possible level of generality: to regulate the acquisition and exercise of power. ${ }^{98}$ It follows that, as a conceptual matter, the antitrust laws could just as easily be used to prosecute a mugging as to prosecute the fixing of the price of organ music. ${ }^{99}$ Suppose that a thief holds you, dear reader, up at knifepoint. He demands your wallet. When you hesitate, he stabs you, whereupon you comply. You comply only because the thief at that moment has a monopoly on a product you are willing to purchase: security. You could take either of two approaches to suing the thief under the

${ }^{96}$ See Convention for the Protection of Human Rights and Fundamental Freedoms, Mar. 20, 1952, 213 U.N.T.S. 262.

${ }^{97}$ See N. Pac. Ry. Co. v. United States, 356 U.S. at 4 (describing the antitrust laws as a "charter of economic liberty"); United States v. Topco Associates, Inc., 405 U.S. 596, 610 (Supreme Court 1972) ("Antitrust laws in general, and the Sherman Act in particular, are the Magna Carta of free enterprise. They are as important to the preservation of economic freedom and our free-enterprise system as the Bill of Rights is to the protection of our fundamental personal freedoms."). It bears noting here that the courts impose few limitations on the kinds of remedies that can be brought to bear on firms that the courts decide have violated Section 2 . The courts have long recognized that the remedy can extend far beyond merely prohibiting the challenged conduct. See GAVIL ET AL., supra note 20, at 1379 ("The most common remedy in civil prosecutions is termination of the unlawful conduct. But simply terminating the conduct would do little to compensate, punish or deter. As a consequence, the typical equitable remedy also includes restrictions on the conduct of the defendant intended to both prevent the conduct from re-occurring and to restore competitive conditions that may have been altered by the conduct."). Courts have, for example, ordered defendants to break themselves into pieces, to make changes to leasing policies, or to provide access to their facilities, or license intellectual property, to competitors at prices dictated by the court. See William E. Kovacic, Designing Antitrust Remedies for Dominant Firm Misconduct, 31 CONN. L. REV. 1285, 1292-1305 (1999).

${ }^{98}$ In a similar vein, it was once remarked to me that the Bible is not a work of literature, but an entire literature in itself.

99 See Complaint at 1, In re Am. Guild Organists, No. C-4617 (Federal Trade Commission May 26, 2017). 
antitrust laws. You could challenge the manner in which the thief acquired this monopoly on security. You might, for example, argue that the fact that the thief bought off the local police force, to ensure that the street would not be guarded, represents an illegitimate mode of acquisition of power. It is an illegal cartel agreement, or merger, in violation of Section 1 of the Sherman Act. ${ }^{100}$ Or you might argue that the way the thief exploited his power so acquired, by stabbing you repeatedly when you resisted, was excessive. It amounted to the exclusion of your body from the market for your own personal security in violation of Section 2 of the Sherman Act. ${ }^{101}$

Why then are the antitrust laws never employed to challenge such conduct, and seem to find application only in the business context? ${ }^{102}$ The answer, of course, is that there are other laws dedicated to regulating the acquisition and exercise of power in other contexts, laws that are tailored to the particular contexts to which they are applied. ${ }^{103}$ The criminal law supplies detailed tests governing the exercise of physical violence. ${ }^{104}$ There is no need for courts to gin up their own replacement out of the vague vastness that is Section 2. The important thing for the purposes of establishing the great overbreadth of the antitrust laws is that courts' failure actually to leverage that overbreadth to colonize other areas of law does not reflect any actual conceptual limitation in antitrust. ${ }^{105}$ The courts' definition of market power

\footnotetext{
100 See supra Section II.A.

101 See supra Section II.A.

102 Actually, antitrust has occasionally been applied to violent conduct. See Ray V. Hartwell III, Criminal RICO and Antitrust, 52 ANTITRUST L.J. 311, 312 (1983) ("For decades before RICO's enactment the activities of organized crime were prosecuted under a broad variety of statutes, including the antitrust laws. For example, although only eleven criminal antitrust cases resulted in jail sentences for businessmen between 1890 and 1940, ten of those cases involved overt acts of racketeering such as threats, intimidation, and violence."). There was even some discussion in the early 1970 s of making antitrust a central part of policy against organized crime. See Michael A. Duggan, Some Lesser Penalties of Antitrust, 8 AM. Bus. L.J. 247, 247 (1971) (recounting that Attorney General John Mitchell proposed applying the antitrust laws to organized crime in an April 1969 address to the Antitrust Section of the American Bar Association); Antitrust Enforcement against Organized Crime Notes, 70 COLUM. L. REV. 307, 331-33 (1970).

${ }^{103}$ Many of these are described infra Section II.D.

104 See generally SANFORD H KADISH \& STEPHEN J SCHULHOFER, CRIMINAL LAW AND ITS PROCESSES: CASES AND MATERIALS 173-516 (2001) (describing the rules governing criminal conduct, rape, and homicide).

${ }^{105}$ For the basic argument that antitrust's confinement to the business context is custom, see supra note 33. The courts also restrict the scope of antitrust's application within the business context whenever the business conduct at issue may be understood to reflect the will of the government. See AREEDA \& HoVENKAMP, supra note 3, ๆ $240 \mathrm{~b}$ ("[A]ntitrust's mandate is to ensure that private discretionary conduct is adequately constrained by government authority. Thus, for example, when a government agent with jurisdiction compels or approves certain behavior, it is not antitrust's job to interfere, notwithstanding our belief that
} 
is capacious enough to swallow all power, including government power, and therefore to enable antitrust regulation of all acquisitions of power. ${ }^{106}$ And the courts' approach to regulating the exploitation of power under Section 2 has been so fluid as to suggest that the courts could use Section 2 to impose any limitation on the exercise of power that the courts wish to impose. ${ }^{107}$

\section{The Other Branches of Law Also Regulate Market Power}

The rest of the law also regulates either the acquisition or exercise of power, which is why a comparison between the ways in which antitrust regulates and the ways in which other areas of law regulate will prove fruitful. Public law, including constitutional law, administrative law, and criminal law, all regulate power associated with control over an input that is essential to every production process, and which the government therefore seeks to monopolize in order to compel obedience: security. ${ }^{108}$ Governments maintain

the behavior is anticompetitive or inefficient, or that welfare would be better served if competition rather than regulation controlled this particular actor. By the same token, however, even when the regulatory mandate is elaborate, antitrust may have room to analyze private conduct that the agency is not authorized to oversee or where authorized oversight is incomplete or lacking entirely."). Antitrust will not, for example, interfere with the government's creation or operation of a monopoly in some business line, such as power generation. See id. at 240c1 (observing that antitrust will not touch business conduct "approved by a regulatory inquiry that took full, statutorily authorized account of competitive effects"). This too is mere custom - judge-made law-and nothing in antitrust's concept of power would prevent antitrust's application to state-created or supported businesses. See Baxter, supra note 84, at 664 (emphasizing the common-law-like character of judicial decisionmaking in antitrust); AREEDA \& HovENKAMP, supra note 3, II 240c1 (treating antitrust's rules regarding state action as judge made).

The United States Congress has also exempted some business activities, from certain business dealings of insurers to certain dealings of shippers, from the application of the federal antitrust laws. See id. III 219, 251. These limits are not a matter of pure custom, of course, but the limits do nothing to alter antitrust's concept of power and therefore the conceptual breadth of antitrust.

${ }^{106}$ See supra Section II.B.

${ }^{107}$ See supra Section II.C.

${ }^{108}$ See MAX WeBER, From MAX WebER: EsSAYS IN SOCIOLOGY 78, 122 (1946) (stating that "a state is a human community that [successfully] claims the monopoly of the legitimate use of physical force within a given territory"); Frederic C. Lane, Economic Consequences of Organized Violence, 18 J. ECON. HIST. 401, 414 (1958) (stating that "protection is in a sense a basic ingredient in nearly every other product"); 1 WEBER, supra note 73, at 54-55. By "monopoly" here I mean sufficient control over the security input to create market power downstream in every single market for which security is an input. By contrast, when antitrust refers to "monopoly," antitrust typically means to refer to the possession of market power in a downstream market, rather than to the control over an essential input in an upstream market that must always be the source of that market power. See Woodcock, supra note 52, at 56 (distinguishing "monopoly power" from "power over inputs"). Thus I am using the term 
their monopoly on security, and its flipside, force, through the criminal law, which prohibits the use of violence other than by agents of the government. ${ }^{109}$ Rules against assault, homicide, and threat prevent nonstate actors from entering the protection market that is dominated by the government. ${ }^{110}$ The thief who tries to sell security to the victim with the offer, "your money or your life," is put in jail. ${ }^{111}$ Only the government can propose such a bargain, or the modern variant, "your tax dollars or your freedom." 112 To be sure, governments sometimes tolerate private security services, or subcontract police functions to private concerns, or recognize a right to bear arms. ${ }^{113} \mathrm{But}$ all these things are circumscribed by the criminal law, which will not allow a private security service to engage in violence not authorized by the state, or a bearer of arms actually to use them against others except in the limited circumstance of self-defense. ${ }^{114}$

somewhat more loosely here.

109 See KADISH \& SCHULHOFER, supra note 104, at 796-809 (discussing the law of use of force by law enforcement officers). Of course, in certain other limited circumstances, such as self defense, the government also permits private persons to use violence. See id. at 74995, 809-31. But such acts of private violence are acceptable only to the extent that they are authorized by the law. See WEBER, supra note 108, at 78 (stating that "the right to use physical force is ascribed to other institutions or to individuals only to the extent to which the state permits it. The state is considered the sole source of the 'right' to use violence").

110 See KADISH \& SCHULHOFER, supra note 104, at 387-516, 572-73, 1080 (discussing assault, homicide, and threat).

111 See id. at 960 (discussing the common law definition of robbery as "a larceny accomplished by violence or threat of immediate violence to the person of the victim").

112 See Lane, supra note 108, at 407-8 (characterizing early governments as demanding "tribute" in exchange for protection and modern governments as demanding "tax" payments).

113 See Heather Elms \& Robert A. Phillips, Private Security Companies and Institutional Legitimacy: Corporate and Stakeholder Responsibility, 19 BUSINESS ETHICS QUARTERLY 403, 409-11 (2009) (discussing the prevalence of private security companies); U.S. Const. amend. II.

114 See District of Columbia v. Heller, 554 U.S. 570, 2015-16 (Supreme Court 2008) (concluding that the right to bear arms in the United States extends only to "weapons typically possessed by law-abiding citizens for lawful purposes); David A. Sklansky, The Private Police, 46 UCLA L. REV. 1165, 1183 (1999) (observing that "tort and criminal doctrines of assault, trespass, and false imprisonment" all apply to private security personnel); KADISH \& SCHULHOFER, supra note 104, at 749-95 (discussing the lawfulness of self defense). To be sure, the right to bear arms is understood to permit private persons to use violence to resist oppressive conduct by the government. Nelson Lund, The Second Amendment, Political Liberty, and the Right to Self-Preservation, 39 ALA. L. REV. 103, 122 (1987) ("The Second Amendment at least gives individuals a constitutional right to keep such private arms as will enable them to constitute a reasonable deterrent against government attempts to institute a repressive political regime.”). But that right is understood to exist only because it is guaranteed, and circumscribed, by law-constitutional law-that itself represents the will of the government. 
Does the centralization of control over force created by the criminal law give rise to market power in the antitrust sense? The answer must be yes. Security is an essential input into the production of everything. ${ }^{115}$ Neither a pencil nor a pedicure can be sold if others cannot be stopped from blowing them up. ${ }^{116}$ And it is self-evident that a government with a genuine monopoly on force, one that can kill or imprison anyone who disobeys, will be able to wield its power over security to induce obedience, whether in the form of compliance with regulatory orders, the payment of taxes, or what have you. Thanks to the force monopoly, the government has the power, in every market, profitably to raise price in the sense described in Section II.B.

There is something not quite right, however, about saying that the criminal law preserves the government's monopoly on force. Laws have power only to the extent that they are enforced, and it is the government itself that enforces the criminal law, using that very same monopoly on force that the criminal law is supposed to guarantee to the government. Because the government enforces its own laws, the criminal law operates here not so much as a protector of government power but rather as an expression of the resolve of government to defend its monopoly on violence, one that, in the United States, the government originally seized from the British in 1783 by force of arms. ${ }^{117}$ The government's force monopoly is not a creature of law, but a practical reality. The criminal law, and ultimately all public law, describes the terms according to which the government aspires to maintain that reality.

If criminal law describes the terms according to which government maintains its monopoly on force, constitutional and administrative law may then be said to describe the limits to which the government chooses to adhere in the exercise of the power created by that force monopoly. Constitutional law delimits the government's exercise of power both by specifying what the government can do and by specifying what the government cannot do. In the United States, constitutional law specifies what the government can do by enumerating the government's powers at the federal level, such as the power to regulate interstate commerce, and reserving all other powers to the states. ${ }^{118}$ Constitutional law in the United States restricts government exercise of power through the Bill of Rights, among other means. ${ }^{119}$ The Bill

\footnotetext{
115 See Lane, supra note 108, at 414.

116 See id.

117 See Edward Countryman, The American Revolution: Revised Edition 131 (2003).

118 See U.S. Const. amend. 10 ("The powers not delegated to the United States by the Constitution, nor prohibited by it to the states, are reserved to the states respectively, or to the people.'); U.S. Const. art. I, sec. 8, cl. 3 (commerce clause).

${ }^{119}$ See U.S. Const. amends. 1-10.
} 
of Rights prohibits the government from extracting confessions by torture, putting people in prison without trial, or taking property without paying for it, to name a few of the restrictions. ${ }^{120}$ But by far the most important way that constitutional law limits the exercise of the government's monopoly on force is by giving the people rights of democratic participation, allowing the public to elect representatives who make the laws and the chief bureaucrat responsible for carrying them out. ${ }^{121}$ The implications of this limitation will be discussed in Section III.B.1.a. Finally, administrative law further limits the exercise of governmental power by defining the scope of authority of government bureaucracies and giving the public a voice in bureaucratic decisionmaking through notice and comment and administrative adjudication processes. ${ }^{122}$

Public law is only the most visible example of the way the law regulates power. Private law does that too. Consider the law of contracts. The breach of a contract is almost always an exercise of market power. Either the market price of the good in question has increased, implying that a surge in demand or a reduction in supply has given the breacher the power to raise the price of the good, or the counterparty's reliance on the contract has eliminated competitors of the breacher and created power to raise price. ${ }^{123}$ If the market

120 See U.S. Const. amend. 8 ("Excessive bail shall not be required, nor excessive fines imposed, nor cruel and unusual punishments inflicted."); In re Kemmler, 136 U.S. 436, 447 (Supreme Court 1890) (interpreting the Eighth Amendment to prohibit torture); U.S. Const. amend. 6 (right to trial for criminal defendants); U.S. Const. amend. 5 (stating that "nor shall private property be taken for public use, without just compensation").

${ }^{121}$ See U.S. Const. art. I sec. 2 cl. 1 (providing that the House of Representatives is to be "chosen . . by the People"); U.S. Const. amend. XVII (providing for the popular election of the Senate); U.S. Const. amend. XII (providing for the election of the President by stateappointed "electors").

${ }_{122}$ See Robert L. Rabin, Federal Regulation in Historical Perspective, 38 StAN. L. REV. 1189, 1265 (1986).

123 See Douglas LAyCOCK, Modern AMERICAN REMEdIES: CASES AND MATERIALs 396401 (4th ed. 2010) (discussing “efficient breach"); Christopher T. Wonnell, Expectation, Reliance, and the Two Contractual Wrongs, 38 SAN DIEGo L. REV. 53, 62 (2001) (A . . . common pattern in which a party would voluntarily choose to enter a contract and then breach it concerns the situational monopoly arising from reliance."). The increase in the market price reflects market power, in the sense of power profitably to raise price, even if, as is usually the case, the increase in market price does not result from anticompetitive conduct by the breacher. See supra Section II.B (discussing market power). The increase in price may be attributable to a surge in demand or a reduction in industry supply, both of which would make the additional profits to be had from breaching and selling at the market price scarcity rents. See David J. Teece \& Mary Coleman, The Meaning of Monopoly: Antitrust Analysis in High-Technology Industries, 43 ANTITRUST BULL. 801, 819-20 (1998). But the definition of market power does not distinguish between sources of power, but instead counts all power profitably to raise price as market power. See Kirkwood, supra note 57 , at 1172 . It is for the law to decide whether and how to regulate such power. 
price has increased, the breacher engages in "efficient breach," by reneging on the contract and selling on the market to a third party at the higher price. ${ }^{124}$ If the counterparty has relied, then the breacher reneges to the end of exploiting his newfound power to renegotiate the deal at a higher price. ${ }^{125}$ The construction firm has foregone opportunities to buy construction materials from others, prepared a foundation for the building, hired labor, and committed to future projects. ${ }^{126}$ The breacher can now insist on a higher price in exchange for supplying the materials, because reliance has left the counterparty with nowhere else to go ${ }^{127}$ In enforcing promises, contract law therefore limits the exercise of market power, forcing promisors to act as though their power had not changed after the signing of the agreement, even though it has. ${ }^{128}$ Some people do, of course, breach contracts out of laziness, carelessness, or because they did not fully understand the implications of their promises. ${ }^{129}$ These examples do not refute the view that contract law regulates market power. Instead, they show that contract law is overbroad, because contract law fails to make proof of market power an element of a contract law claim, and so occasionally proscribes conduct that does not represent an exercise of market power. In antitrust parlance, contract law uses "per se" rules to regulate the exercise of power, and these sacrifice accuracy for ease of application. ${ }^{130}$

The association of property law with market power is already well known. ${ }^{131}$ Property law regulates the acquisition of control over inputs by private persons by setting the conditions under which a person may acquire title. In particular, property law insists that title be acquire either through trade or creation. Thus property law does not recognize title in thieves or badfaith purchasers, but property law does recognize title in items voluntarily transferred, usually as part of trade, in manufactures - new things produced by the owner from inputs lawfully acquired - as well as, through the intellectual property laws, limited title in inventions. ${ }^{132}$ These rules operate

\footnotetext{
124 See LAYCOCK, supra note 123, at 396-401.

125 See Wonnell, supra note 123, at 62.

${ }^{126}$ See id.

127 See id.

${ }^{128}$ See LAYCOCK, supra note 123, at 42 (stating that it is well-settled that plaintiff is entitled to expectation damages for breach of contract, which are designed to put the plaintiff in "the position plaintiff would have occupied if the contract had been performed").

${ }^{129}$ See Wonnell, supra note 123, at 72-79 (discussing mistake).

${ }^{130}$ See United States v. Topco Associates, Inc., 405 U.S. 596, 607-8 (Supreme Court 1972).

${ }^{131}$ See, e.g., Harold Demsetz, Barriers to Entry, 72 AM. ECON. REV. 47, 79 (1982) (stating that "the problem of defining ownership is precisely that of creating properly scaled legal barriers to entry" into markets, and hence market power).

${ }^{132}$ See JeSSE DUKEMINIER ET AL., PROPERTY 56, 98-100, 161, 605 (7th ed. 2010) (discussing acquisition of property rights by creation and by delivery of title, good-faith purchasers of
} 
to channel private control over inputs away from those who seek to acquire control by force. That supports the government's force monopoly and also promotes economic growth by rewarding those who acquire wealth through trade or creation rather than through redistribution. ${ }^{133}$

Tort law guarantees the private owner's control over property lawfully acquired, much the way the criminal law guarantees government's control over the force monopoly, by deterring actions by those who would interfere with that control. The torts of ejectment and trespass give rise to an injunction which forces the tortfeasor to relinquish control and a judgment for damages, and trespass's criminal law analogue further reinforces property law's determinations regarding control over inputs. ${ }^{134}$ Intellectual property law's trespass analogue, the claim for infringement, does the same for the title determinations made by intellectual property law. ${ }^{135}$ Tort law also serves to reinforce the criminal law's preservation of the government's force monopoly, by allowing victims of private violence to seek financial compensation from wrongdoers, magnifying the deterrent effect of criminal

stolen property, and the general rule that the title of the "true owner" is good against the whole world, including finders and thieves); ROBERT P MERGES ET AL., INTELLECTUAL Property IN THE NEW TEChNOLOGICAL AGE 123-428 (6th ed. 2012) (describing patent law).

133 See Robert CoOter \& Thomas Ulen, LAW \& ECONOMics 76-80 (6th ed. 2012) (discussing the economic advantages of property law).

134 See Lawrence S. Greenwald \& Charles S. Hirsch, Personal Liability of Corporate Officials in Ejectment Actions: Evolution of the Tort and the Implications of Metromedia Co. v. WCBM Maryland, Inc., 22 U. BALT. L. REV. 37, 37-38 (1992) (classifying ejectment and trespass as torts); LAYCOCK, supra note 123, at 606-7, 754-57 (discussing ejectment and trespass); Laurent Sacharoff, Criminal Trespass and Computer Crime, No. ID 3569836, 3436 (2020) (discussing state criminal trespass laws). Law and economics scholars often argue that because the principal measure of damages in tort is the harm to the victim, tort actions are not so much about prohibiting conduct as about forced sales of rights at a price equal to the cost of the right to the victim, meaning the harm inflicted by the violation of the right. See LAYCOCK, supra note 123, at 16-17 (discussing the law and economic approach). Thus a trespass is just the forced sale of the right to be on the property by the owner to the trespasser at a price equal to the harm caused by the trespass, understood to be the cost of the right to the owner. While this interpretation works for unintentional torts, discussed in the next paragraph, it fails for intentional torts, including the tort of intentional trespass that supports the property system, because plaintiffs are not just entitled to damages measured by actual harm for intentional torts, but to disgorgement of any profits generated by the trespasser. See id. at 654-55. The remedy for trespass may therefore be understood effectively to prevent a trespasser from enjoying the fruits of using illegal control over a particular input profitably to raise prices. The tort of trespass supports the property regime after all, by ensuring that any power derived from exerting control not authorized by property law cannot fruitfully be exercised.

135 See MERGES ET AL., supra note 132, at 65-106, 295-367, 542-533, 868-953 (discussing trade secret misappropriation and patent, copyright, and trademark infringement). 
prohibitions on private violence. ${ }^{136}$

The tort of trespass plays a supporting role in property law's allocation of control over physical objects among private persons. But tort law also directly determines control over other kinds of inputs. In particular, the unintentional torts of negligence and strict liability may be understood to allocate title to the input called risky conduct, which is an essential component of many production processes. ${ }^{137}$ A rule of strict liability for polluting rivers, for example, effectively gives the public ownership of the risk of harm created by polluted rivers, one that firms must then purchase from the public in the form of damages awards if they wish to pollute. ${ }^{138}$ The rule that it is negligent to toss banana peels over your shoulder, because someone could slip on them, allocates control over that risky conduct-a possible input into the production of a lunchtime walk in a neighborhood without trash cans - to victims, who then sell it back to walkers when they sue walkers for damages. ${ }^{139}$

Finally, contract law has a second use, derivative of its principal use blocking the exercise of post-signing market power. That use is to enable the centralization of control over inputs by enabling independent owners to exercise their control rights according to a common plan. ${ }^{140}$ By preventing contracting parties from using market power to hurt each other after signing their contract, contract law makes this sort of centralization of control through cooperation easier to accomplish. ${ }^{141}$ As does the law of agency, that oft-overlooked backbone upon which all business forms, from the partnership to the corporation, are built. ${ }^{142}$ By creating a duty in agents to act

136 See Mark Geistfeld, Tort Law and Criminal Behavior (Guns) Guns, Crime, and Punishment in America, 43 ARIZ. L. REV. 311 (2001) ("The relation between tort liability and criminal behavior goes back to the very origins of the tort system. Originally, tort damages were awarded as an incident of criminal prosecution, and the linkage of criminal and tort liability meant that the early common-law courts approached the field of tort through the field of crime. Tort actions continued to be quasi-criminal until the late seventeenth century.") (internal quotation marks omitted).

137 See, e.g., HAL R. VARIAN, InTERMEDIATE MiCROECONOMICS: A MODERn APPROACH 632-39 (7th ed. 2006) (discussing the sale of pollution rights).

${ }^{138}$ See, e.g., id.

139 See, e.g., id.

140 See Woodcock, supra note 39, at 139 (observing that one way to exclude competitors from a market is to "use contract . . . to coerce the owner or owners of . . . inputs to exclude competitors").

${ }^{141}$ See COOTER \& ULEN, supra note 133, at 283 (characterizing contract law as facilitative of cooperation).

142 See Charles R. T. O'Kelley \& Robert B. Thompson, Corporations and Other Business Associations: CASES AND MATERIALs (2017); Donald C. Langevoort, Agency Law inside the Corporation: Problems of Candor and Knowledge Sixteenth Annual Corporate Law Symposium: Agency Law inside the Corporation, 71 U. CIN. L. REV. 1187, 
for the benefit of the principal, the figure that, in all business forms, is the business entity itself understood as a fictive person, agency law in effect forces agents to work together to operate the property of the principal in centralized manner, as if there were a single unitary intelligence exercising the power created by the inputs owned by the principal, even when there is none (where the principal is a partnership, corporation, or other business association), or the agents are so numerous that a human principal would not be able to direct all of their actions in detail (as in a large business run as a sole proprietors ship). ${ }^{143}$ This outcome could in theory be accomplished through the conclusion of contracts with agents specifying their actions in great detail, but in practice the writing and rewriting of contracts sufficiently detailed to address all possible future events that agents might encounter is impossible. ${ }^{144}$

Taken together, public and private law constitute an entire legal regime dedicated to the regulation of the acquisition and exercise of market power, one that differs from antitrust not in breadth, but in content and approach. ${ }^{145}$ Criminal law centralizes the government's control over an input that is essential to all economic life - security - enabling the government to use the market power that flows from control of such a valuable input to require adherence to law throughout all of the supply chains that crisscross the economy, all of which need security and so must obey. ${ }^{146}$ Constitutional and administrative law then act to limit the government's exercise of this monopoly over security. ${ }^{147}$ In contrast to public law, which governs only the force monopoly, private law rules govern the acquisition and exercise of power attributable to control over all other inputs in the economy. Private

1188, 1191 (2002-2003) ("To many legal academics, agency law is a backwater subject, long banished from the formal law school training except for brief introductory reference in corporations or business associations. . . . That corporation law builds on the foundation of agency law is beyond doubt. Almost every corporate employee with discretionary responsibilities is an agent, and agency principles are frequently invoked in corporate law disputes.).

${ }^{143}$ See, e.g., E. Merrick Dodd, For Whom Are Corporate Managers Trustees?, 45 HARV. L. REV. 1145, 1146 (1932) ("The corporation as a distinct legal person is now conceived of as carrying on the business and making the contracts, and the directors and other agents are fiduciaries for it."); Langevoort, supra note 142, at 1191 ("Having created the corporation as a distinct juristic entity for a variety of historical and economic reasons, the law has to allocate the rights, power, and responsibility to some person or group actually able to make the choices principals are normally entitled to make.").

${ }^{144}$ See COOTER \& ULEN, supra note 133, at 291-92 (discussing the impossibility of "perfect contracts").

${ }^{145}$ For the argument that the antitrust laws regulate all power, see infra Section II.B.

146 See Lane, supra note 108, at 414.

${ }^{147}$ See supra paragraph accompanying note 118. 
law serves to determine which private persons control which inputs (property, intellectual property, and parts of tort law), to enable private persons controlling different inputs to centralize control over them by acting as one (contract), to enable those in control of great masses of inputs to organize their use coherently (agency), and to prevent abuses of power that might interrupt cooperation between different controllers (contract). Despite its conceptual breadth, antitrust as currently practiced interacts only with this private law world. Antitrust acts as a private law overlay, stepping in, under certain circumstances, to break up centralizations of control in private hands created through contract, property, or agency, and limiting the exercise of the power created by such centralizations in others. ${ }^{148}$ Antitrust does this regardless of the input in question, save one: the security input that underpins government power, which antitrust never touches. ${ }^{149}$

\section{The DifFERING APproAches OF ANTITRUST AND THE StATE TO Power}

\section{A. The Acquisition of Power}

\section{Antitrust}

Antitrust takes a strikingly general approach to acquisitions of power, seeking to condemn all acquisitions that do not appear conducive to higherquality or lower-cost production. ${ }^{150}$ All acquisitions of power in a particular market derive from centralization of control over an upstream input into the production process, which enables the firm to deny access to the input to competitors, drive competitors from the market as a result, and thereby to place consumers in a position of dependency with respect to the firm's own products. ${ }^{151}$ In prohibiting acquisitions of input control that do not increase quality or lower production costs, antitrust takes the position that firms should be permitted to acquire control over inputs, whether through outright purchase or by contracting with the inputs' owners, so long as the control is

\footnotetext{
148 See infra Part III.

149 See AREEDA \& HovENKAMP, supra note 3, ๆ 200 ("[A]ntitrust's intervention into the political process is inappropriate once it is determined that the government itself rather than a private actor is the relevant decision maker.").

150 See Ramsi A. Woodcock, The Obsolescence of Advertising in the Information Age, 127 YALE L.J. 2270, 2309-13 (2018) (arguing that antitrust prohibits "disabling" conduct, meaning conduct that reduces the quality or increases the price of competitors' products without increasing the quality or reducing the price of the defendant's own products); Woodcock, supra note 52, at 54-55.

${ }^{151}$ See Woodcock, supra note 39, at 137-41; Woodcock, supra note 52, at 55-56.
} 
productive in an economic sense. ${ }^{152}$

Antitrust cannot prohibit all attempts to centralize control over inputs because firms are themselves just bundles of inputs: office space inputs, management inputs, factory machine inputs, and so on. It is really only the firm's output - the particular products that the firm produces - that determines the market in which the firm competes. ${ }^{153}$ All the rest of the firm actually stretches up vertically into upstream supply markets. ${ }^{154}$ Indeed, the centralization of control over inputs is constitutive of all productive activity, which amounts to the bringing together of components - inputs - to produce something that is greater in value to society than the sum of its parts. ${ }^{155}$ If firms do not centralize control over at least some inputs, then consumers must undertake the impossible task of choosing on their own, from the list of all inputs in the economy, which components to combine to obtain the products they want. ${ }^{156}$

Antitrust takes account of the virtues of input centralization by examining its effects: if the effect is to make a better product or the same product at a lower cost, then the centralization is benign. ${ }^{157}$ Otherwise, it is harmful and prohibited. ${ }^{158}$ For example, antitrust makes illegal per se all agreements between competitors that have the fixing of prices or the allocation of markets as a primary purpose. ${ }^{159}$ Such agreements do not involve the integration of the management or productive processes of the member firms, so it is difficult to see how they would enable better or lower-cost production. ${ }^{160}$ But they do centralize control over inputs into the production process, because the agreements effectively cause the firms to use their pooled control over their inputs to negotiate as a unit with customers. ${ }^{161}$

Antitrust also sometimes prohibits the outright purchase of competitors

152 To be precise, the consumer welfare standard requires not only that the control be productive but that the benefits be passed on to consumers through lower prices in the case of cost reductions. See Salop, supra note 21, at 336-38.

153 HovenKaMP, supra note 3, at 119 ("[P]roduct [market] definition depends on [the] substitutability [of the products in the market] in consumers' eyes[.]").

${ }^{154}$ See id. at 489 (stating that "all firms are vertically integrated to some degree").

155 See AlFRED MARSHALl, PRINCIPLES OF ECONOMICS 53 (8th ed. 1920) ("All that [man] can do in the physical world is . . to readjust matter so as to make it more useful[.]").

156 See Lon L. Fuller, Some Reflections on Legal and Economic Freedoms--A Review of Robert L. Hale's Freedom through Law, 54 CoLuM. L. REV. 70, 72 (1954).

157 See Woodcock, supra note 150, at 2309-13.

158 See id.

159 See AREEDA \& HoVENKAMP, supra note 3, IIT 2004, 2006 (discussing the per se rules against price fixing and market division).

160 See id.

161 See Woodcock, supra note 39, at 139. 
because that too can centralize control over inputs. ${ }^{162}$ Competitors control inputs, including not just raw material inputs, but also the specialized management talent required for success in particular markets. Mergers bring control over those inputs together under a single decisionmaking structure. ${ }^{163}$ But antitrust is much more careful here, evaluating the agreements on a case by case basis, as opposed to banning them all outright, as is the case for price fixing and market division agreements, because acquisitions lead to an integration of facilities and management, and therefore can potentially lead to product improvements or cost reductions. ${ }^{164}$ If acquisitions lead to such efficiencies, and courts believe that consumers will benefit from them, then the courts will generally permit the acquisitions to take place. ${ }^{165}$

Purchasing competitors and contracting with them are examples of attempts to exert control over inputs in a horizontal fashion, by exerting control over the bundles of inputs that are competing firms. ${ }^{166}$ Antitrust takes a more permissive approach to attempts by firms to exert control over inputs directly, by buying inputs from upstream suppliers that do not compete with the firms because they do not themselves use the inputs to produce outputs, or do not use the inputs to produce the same outputs as do the acquiring firms. There is no per se rule against such "vertical" acquisitions or agreements, in contrast to the per se rule against price fixing by competitors. ${ }^{167}$ Instead, both the outright purchase of inputs and their control through contracts with suppliers are considered by antitrust on a case-by-case basis. ${ }^{168}$ If the courts believe that vertical acquisitions or contracting have no efficiency justification, and tie up-or "foreclose," in antitrust terminology-a sufficiently large portion of the inputs that they are likely to lead to market

\footnotetext{
162 See AREEDA \& HOVENKAMP, supra note 3, III 901a, 902a, $902 \mathrm{~b}$ (discussing the antitrust treatment of horizontal mergers).

163 See Woodcock, supra note 39, at 148 ("Merger law regulates the achievement of centralized ownership through the process of acquiring inputs in a given market."); EDITH Penrose \& Edith Tilton Penrose, The Theory of the Growth of the Firm (1995) (arguing that the motivation for many mergers is the acquisition of specialized managerial knowledge).

164 See AREEDA \& HOVENKAMP, supra note 3, II 901a.

165 See HovENKAMP, supra note 3, at 631 (stating that "the unifying theme of the Horizontal Merger Guidelines is to prevent the enhancement of market power that might result from mergers . . . . [A] merger enhances market power if it is likely to encourage one or more firms to raise price, reduce output, diminish innovation, or otherwise harm customers as a result of diminished competitive constraints or incentives.").

166 See id. at 630 (defining horizontality in the merger context).

${ }^{167}$ See id. at 489 (defining vertical integration).

168 See AREEDA \& HOVENKAMP, supra note 3, at 512-13, 573 (describing the case-specific analysis applied by courts in vertical merger and exclusive dealing cases).
} 
power downstream, then they will ban the acquisition or contracts. ${ }^{169}$

Probably the most important rule in antitrust regarding the acquisition of power is an exemption, rather than a prohibition, however. It is the rule that power achieved through innovation-sometimes called "Schumpeterian power" for the scholar who first drew attention to its importance-is always permissible. ${ }^{170}$ Schumpeterian power is market power based on a firm's control over an input that the firm has invented, rather than merely acquired from others. ${ }^{171}$ It is also market power based on control over an input that was given some new significance in the market by the creative activities of the firm. ${ }^{172}$ The inventors of a better way to produce headlights for cars cannot be forced to disclose the process in order to reduce the inventor's power to dictate prices for the headlights to car manufacturers. ${ }^{173}$ By the same token, the owner of all the graphite on earth who invents the pencil cannot be required to divest himself of his holdings of graphite, even though his control over the graphite makes it impossible for other firms to produce their own pencils. ${ }^{174}$ (By contrast, if the pencil company were to buy up the world's graphite after inventing the pencil, the exemption would not apply, because then the firm's power would be due to vertical acquisitions, rather than the act of invention. Courts might well block the purchases on the ground that they foreclose too much supply to competitors. ${ }^{175}$ )

\section{The State}

The exemption for Schumpeterian power, which I call antitrust's rule of "innovation primacy," is really just the rule permitting centralizations of control that better products or reduce costs that appears in the law of horizontal and vertical agreements. ${ }^{176}$ Innovation primacy applies the rule more generally to all conduct, not just to agreements. ${ }^{177}$ Cost reductions and

\footnotetext{
169 See HovenKAMP, supra note 3, at 502-3, 564-65.

170 See Teece \& Coleman, supra note 123, at 820-22 (discussing Schumpeterian rents); Woodcock, supra note 150, at 2311-14 (discussing innovation primacy).

171 See Woodcock, supra note 150, at 2311-14.

172 See Woodcock, supra note 39, at 139 ("Firms often [obtain power] not by taking control of all the potential inputs in a given market but by transforming the product in a given market into one for which they already control or may be able to achieve control over all the potential inputs.").

173 See Woodcock, supra note 150, at 2311-14.

${ }^{174}$ See Woodcock, supra note 39, at 139.

175 See HoVENKAMP, supra note 3, at 164-65.

176 See supra Section III.A.1.

177 That is, the innovation primacy concept is part of the rule of reason, which applies to both group behavior under Section 1 of the Sherman Act and to single-firm conduct under Section 2 of the Sherman Act. See Mark S. Popofsky, Defining Exclusionary Conduct: Section 2,
} 
product improvements are both at heart always the result of inventive activity. ${ }^{178}$ So antitrust really only has one broad rule governing power acquisition: that centralization must make the acquirer's product better in the sense of more desirable or less costly. ${ }^{179}$ There is no equivalent in public law's approach to the force monopoly. The U.S. Constitution does not, for example, state that the United States will continue to maintain its monopoly on force within the 50 states so long as the maintenance of that monopoly renders the people themselves more secure, which would be the equivalent of antitrust's innovation primacy concept in public law. Instead, the criminal law is more or less fixed and the power of legislatures under the Constitution to maintain it that way is more or less unchallenged. ${ }^{180}$

Indulging an analogy between the state and the business firm helps explain why public law does not question the force monopoly. To question the monopoly would be equivalent to a business firm questioning whether the firm should have a monopoly. To the extent that the doctrine of shareholder primacy is the law today - a contested question, to be sure - no firm would do that, because relinquishing the monopoly would reduce the power of the firm and by extension the firm's ability to extract profits from the market. ${ }^{181}$ There was a time when state legislatures placed provisions in corporate charters that were designed to limit firms' ability to acquire monopoly power, the prohibition on ownership of other corporations being the most famous. ${ }^{182}$ A constitutional provision prohibiting the acquisition of overseas colonies might be the equivalent at the state level, but none actually exists, at least in American public law. ${ }^{183}$

The Rule of Reason, and the Unifying Principle Underlying Antitrust Rules Symposium Identifying Exclusionary Conduct under Section 2, 73 ANTITRUST L.J. 435, 437 (2005-2006) (observing the rule of reason applies both to Section 1 and Section 2).

${ }^{178}$ See Frederic M. Scherer, First Mover Advantages and Optimal Patent Protection, $40 \mathrm{~J}$. TECH. TRANSFER 559, 562-64 (2015) (contrasting product and process innovation).

179 See Woodcock, supra note 150, at 2311-14.

180 See Engle v. Isaac, 456 U.S. 107, 128 (Supreme Court 1982) (referencing the states' "sovereign power to punish offenders").

181 See Ramsi A. Woodcock, The Antitrust Case for Consumer Primacy in Corporate Governance, 10 UC IRVINE L. REV. 1426-33 (2020) (discussing shareholder primacy and surveying the arguments against shareholder primacy).

182 See Morton J. Horwitz, The Transformation of AMERICAN LAw, 1870-1960 83 (1992); AREEDA \& HOVENKAMP, supra note 3, II 102c3. Such holding company prohibitions prevented firms from conducting operations in multiple states because courts at the time followed the foreign corporation doctrine, which held that the laws of one state need not recognize the existence of a corporation created in another state. See HoRWITZ, supra, at 78-79 (discussing "foreign corporations"); AREEDA \& HOVENKAMP, supra note 3, II 102c3. 183 See Simeon E. Baldwin, The Constitutional Questions Incident to the Acquisition and Government by the United States of Island Territory, 12 HARV. L. REV. 393, 405 (1899) (stating that "the Constitution is the supreme law wherever the flag of the Union floats over 
To find rules governing the centralization of power at the level of the state, one must move one level up from constitutional law to international law, which decides which governments should have a monopoly on security in which areas of the globe based on a consensus of currently-existing governments. ${ }^{184}$ The analogue, in the antitrust context, would be a doctrine authorizing market division. ${ }^{185}$ Under such a doctrine, existing owners of essential inputs into a given market would be authorized to decide among themselves whether and when to allow a new firm to enter the market. This is in fact the normal method by which cartels operate industries, and it has even received official sanction historically in some jurisdictions. ${ }^{186}$ During the First New Deal, the Roosevelt Administration encouraged such behavior. ${ }^{187}$ And Germany promoted this approach in its domestic markets until World War Two. ${ }^{188}$

Private law, in the way it regulates the acquisition of power over inputs other than security, takes an approach closer to that of antitrust than does public law. ${ }^{189}$ Indeed, property law follows in rough outline the same approach as antitrust in that property law grants control over resources to those who either create the resources themselves, or acquire them through trade. ${ }^{190}$ Both creation and (voluntary) trade are productive activities - in the case of trade the purchaser must place a higher value on the good than the seller, ensuring that the resource moves to a higher valued use-and so a rule approving of centralizations of control incident to those activities does approximately what antitrust does in approving centralizations that result in better products or lower prices. ${ }^{191}$ But antitrust's rule is more precise than property law's rules, and in particular recognizes that although all property

its soil").

184 See BRAD R. ROTH, GOVERNMENTAL ILLEGITIMACY IN INTERNATIONAL LAW 1 (2000) (discussing "collective non-recognition of government in international law").

${ }^{185}$ Cf. United States v. Topco Associates, Inc., 405 U.S. 596, 614 (Supreme Court 1972) (holding division of markets illegal per se under the antitrust laws).

186 See F. M SchERER \& DAVID Ross, Industrial MARKET STRUCTURE AND ECONOMIC PERFORMANCE 236 (3d ed. 1990) (discussing "sphere of interest agreements" as a form of cartel organization). To the credit of the international community, the focus of the global force cartel in determining membership does seem to focus on consumer welfare, if popular sovereignty can be understood as such. See ROTH, supra note 184, at 1 . Business cartels are probably less likely to determine membership based on a firm's ability to satisfy consumers. 187 See Anne Fleming, Anti-Competition Regulation, 93 BUSINESS HISTORY REVIEW 701, 711 (2019) ("The spread of entry restrictions then accelerated during the New Deal[.]").

188 See DAVID J. Gerber, LAW AND COMPETITION IN TWENTIETH CENTURY EUROPE: Protecting PROMETheus 75 (2010) (observing that German cartels had the power to force members "to abide by cartel rules ... through boycotts").

189 See supra Section II.D.

${ }^{190}$ See supra Section II.D.

${ }^{191}$ See VARIAN, supra note 137, at 15-16 (discussing gains from trade). 
rights attributable to creation are productive, some attributable to trade may not be, because the buyers are paying for the value that comes from denying the purchased item to competitors, rather than for the value that comes from putting the item to good use. ${ }^{192}$ It is for this reason that antitrust may be seen as an adjunct to property law, eliminating those parts of property law that would grant control unproductively. ${ }^{193}$

\section{B. The Exercise of Power}

\section{Antitrust}

\section{a. Charging High Prices and Vertical Integration as Exercises of Power}

The distinction between the acquisition and exercise of power sometimes appears so fine as to be without a difference, but in fact it is crucial to the regulation of power. Acquisition is to exercise as title to property is to the action for ejectment. ${ }^{194}$ One can have the title-granted power to kick a person off of one's property but not actually do any kicking, or kick slowly, or partially. Property law scholars sometimes take for granted that power will be exercised to the fullest possible extent, so much so that they define property as the right to exclude, as if title and the action for ejectment were one and the same. ${ }^{195}$ But in fact title is a mere precondition for the exercise of power, a necessary condition, to be sure, but one that need not automatically give rise to a right to exclude, or exclude completely. The same goes for other modes of centralization of control over inputs, such as contracts between property owners. ${ }^{196}$ There is always the additional question to what extent someone who has centralized control over inputs and so has acquired the potential to exercise great power should in fact be allowed to wield the power. That is why the problem of the exercise of power is analytically distinct from the problem of the acquisition of power. The question here is not whether to kill the giant (the question of power acquisition) but whether to bind him in chains (the question of power

\footnotetext{
192 See Ramsi A. Woodcock, Uncertainty and Reverse Payments 111 (2016) (pointing out in the context of reverse payment patent settlements that a monopolist can use monopoly profits to purchase the withdrawal of competitors).

193 See Ramsi A. Woodcock, The Market as a Learning Algorithm: Consequences for Regulation and Antitrust, No. 3661971, https://ssrn.com/abstract=3661971.

${ }^{194}$ See LAYCOCK, supra note 123, at 606-7, 756 (discussing ejectment).

195 See William BlaCKSTONE, COMMENTARIES ON THE LAWS OF ENGLAND, Volume 2: A FACSIMILE OF THE FIRST EDITION OF 1765-1769 2 (2015) (defining property as "that sole and despotic dominion which one man claims and exercises over the external things of the world, in total exclusion of the rights of any other individual in the universe").

${ }^{196}$ See supra Section II.D (discussing the use of contracts to centralize control over inputs).
} 
exercise).

The most basic way in which a firm can use an input to exercise power is to sell the input at a high price. ${ }^{197}$ In this case, the firm does not compete in the downstream market in which products that incorporate the input are sold, because the firm does not actually produce the downstream product. ${ }^{198}$ The firm is content to be a supplier. The firm's insistence upon selling at a high price is nevertheless an exercise of power in the downstream product market. ${ }^{199}$ The price the firm charges to supply the input becomes part of the cost of production of the downstream product and so is eventually passed on to consumers of the downstream product in the form of higher prices. ${ }^{200} \mathrm{But}$ because the firm does not make the downstream product itself the firm operates as a kind of phantom monopolist in relation to consumers, felt but not seen.

Almost always, however, the input monopolist goes further, and sells the input over which the monopolist has control in conjunction with other inputs as a finished product. That is, the firm competes directly in the downstream market. The reason this is almost always the case is that a firm very rarely sells a product over all of the components of which the firm has the same level of control, and therefore rarely sells a product in which other firms do not have an interest in virtue of having control themselves over some of the product's components. Even the owner of all the gold in the world is unlikely just to sell gold. Instead, the owner might sell gold delivered in New York City on June 29, in which case the owner sells gold plus distribution services that bring the gold to New York at a particular time. If the gold owner does not have a monopoly on distribution services, which seems unlikely since just about anyone owning a car might in theory be able to compete to some extent in the transportation of gold, then the gold that the owner sells-not just gold plain and simple but gold for delivery in New York City on June 29 - is a compound product and the gold owner is vertically integrated into a downstream market of delivered gold that incorporates gold as an essential input.

By contrast, if the input monopolist were to have a monopoly over all of the components of a compound product, then it would serve no purpose to consider the monopolist as participating in a downstream market. No one

\footnotetext{
197 See W. KIP VISCUSI ET AL., ECONOMICS OF REGULATION AND ANTITRUST 266-67 (5th ed. 2018) (considering the case of an input monopolist that raises input prices without integrating vertically).

198 See HovenKAMP, supra note 3, at 543-44 (noting that a firm that sells an input directly to consumers can usually extract the same amount of profit from them as it would be able to extract by selling the input combined with others to consumers).

199 See VISCUSI ET AL., supra note 197, at 266-67.

${ }^{200}$ See id.
} 
save the monopolist would have any hope of participating in that market; all the elements required for participation would already be in the monopolist's hands alone. The downstream market would not be a downstream market at all, but just the market for one big compound input controlled by the monopolist. Indeed, because any thing is always just a collection of other things - gold is a collection of protons and neutrons, for example - all input monopolies are really collections of monopolies over collections of inputs. ${ }^{201}$ Whether monopolies on inputs are to be tolerated is a matter for regulators of the acquisition of power to consider. ${ }^{202}$ The exercise of power comes into play only once the monopolist of inputs starts to combine them with inputs over which the monopolist has less control, bringing the firm into contact with other businesses that supply those inputs and creating subjects upon which the monopolist's power can act.

Once an input monopolist integrates vertically into a downstream market, as opposed to supplying an input to that market, the exercise of power grows beyond the basic question what price to charge for the monopolized input. The firm now necessarily does business directly with consumers, because the firm now sells the finished product, and so the firm now faces the new question what price to charge for the finished product, rather than the input. $^{203}$ The phantom monopolist, from the perspective of consumers,

201 The monopolist of gold is really a monopolist of multiple gold components because the monopolist of gold controls all of the protons-bound-to-neutrons in the proportions required for gold and all of the neutrons-bound-to-protons in the proportions required for gold. See JOHN GRIBBIN \& MARY GRIBBIN, ALMOST EVERYONE'S GUIDE TO SCIENCE: THE UNIVERSE, LIFE, AND EVERYTHING (2015). To be sure, the gold monopolist does not control all protons and all neutrons. Those are supplied in vast quantities everywhere. See id. But neutronsbound-to-protons in the proper proportion and protons-bound-to-neutrons in the proper proportion are quite rare, for they can be bound stably to each other in the proportions needed to make gold only in the hearts of stars. See Joseph Stromberg, All the Gold in the Universe Could Come From the Collisions of Neutron Stars, SMITHSONIAN MAG., https://www.smithsonianmag.com/science-nature/all-the-gold-in-the-universe-could-comefrom-the-collisions-of-neutron-stars-13474145/ (last visited Sep. 5, 2020). The fact that protons-bound-to-neutrons and neutrons-bound-to-protons in the proper proportions always appear physically locked together does not make them any less separate components, although it does conveniently ensure that if you monopolize one you monopolize the other. 202 See supra Section III.A.

${ }^{203}$ In cases in which consumers take on the task of assembling a product, as when students buy pencils and erasers separately but use them together, the input monopolist sells the input directly to the consumer from the start. See HoVENKAMP, supra note 3, at 543-44 (using the example of glass jars and lids). Vertical integration here means that the firm now undertakes to assemble the product on behalf of consumers, selling eraser-tipped pencils for example. See id. In cases in which consumers do not typically assemble the finished product themselves, the input monopolist starts out by selling the input to other firms that incorporate it into a finished product that is then sold along to consumers. In these cases, the input monopolist sells directly to consumers only once it integrates vertically and starts assembling 
becomes a monopolist in the flesh. Of even greater interest, the firm also now exercises power over other firms that produce the same product, because those firms must buy the monopolized input from the firm. Unlike in the case of the unintegrated input monopolist, now the monopolist may choose not to supply the input to downstream producers at all, because the monopolist now can reach consumers directly by making its own version of the product. ${ }^{204}$ So the firm faces the choice between selling to downstream competitors at prices designed, as before, to extract the maximum possible profits ultimately from the consumers who buy the competitors' products, or refusing to sell to competitors, driving them from the market, and extracting all profits from consumers directly through the prices the firm charges to them for the downstream product. ${ }^{205}$ The gold monopolist can choose to sell gold-in-theground to other firms that may want to compete to sell gold for delivery in New York City on June 29, or the gold monopolist may cut them off, and insist on distributing all of its own gold. ${ }^{206}$

But why should a firm ever bother to sell an integrated product when the firm can use the price at which the firm supplies the input to others to determine the price paid by consumers for the downstream product and thereby to extract whatever level of profit the firm wishes to extract from consumers acting as a phantom monopolist in relation to them? ${ }^{207}$ The answer is that the firm may be able to drive up the willingness of consumers to pay for the finished product by making that product itself, as opposed to selling the monopolized input to others for processing into the product. Sometimes this increase in willingness to pay arises because the input owner is able to combine the components that make up the product in a way that makes the finished product better than what other producers are able to produce. ${ }^{208}$ In this case, the input owner effectively controls a second input-

and selling the finished product itself.

${ }^{204}$ See SCHERER \& ROSS, supra note 186, at 524 ("[The monopolist] can refuse to sell the input to [downstream competitors], driving them out of business.").

${ }^{205}$ See id.

${ }^{206}$ See id. The firm can also use the threat of driving competitors from the market to regulate their behavior, although in general business enterprises are interested only in the payment of cash. But governments, by contrast, regularly use the threat of denial of supply of the security input to extract behavioral concessions from downstream enterprises, such as a businessman's choice to refrain from polluting the environment. See Eva M. Fromm, Commanding Respect: Criminal Sanctions for Environmental Crimes, 21 ST. MARY's L.J. 821, 824-48 (1990) (listing "federal environmental laws containing criminal provisions").

207 See HovENKAMP, supra note 3, at 543-44.

208 See id. at 493, 537 (stating that "[a] firm simply becomes dissatisfed with the way someone else is providing a service and believes it can do better itself" and observing that Apple prevailed in litigation regarding the tying of iTunes music libraries to the iPod because "the redesigns were genuine product improvements"). The firm may also be able to reduce 
knowledge regarding how to make a better product - that other firms lack, one that enables the firm to extract more value from consumers by manufacturing the product itself than by selling the input to outside firms that will not assemble the product as effectively. ${ }^{209}$

A great deal of the vertical integration arises because the input owner believes that it can do better than the market at producing the finished product. ${ }^{210}$ But often also a firm will integrate downstream in order to avoid becoming the victim of a monopolist of some other input required to produce the product. ${ }^{211}$ If another firm controls another component of the product, then the two will become locked in battle to determine how they divide the profits generated by selling at high prices to consumers. ${ }^{212}$ The input monopolist's adversary will be able to threaten not to purchase inputs from the input monopolist unless the input monopolist reduces its prices, allowing the adversary to reap all of the gains from charging high prices downstream to consumers. The input monopolist will not be able to neutralize the threat by supplying inputs to other firms, because the adversary controls an essential input into the finished product and so no other firm will be able to incorporate the input monopolist's input into a finished product and sell it to consumers, leaving the input monopolist without a market for its input. By taking a hand in the production of the finished product, the input monopolist protects its ability to do business directly with consumers without having to

production costs thanks to the integration, a result that, from the perspective of the firm, is tantamount to increasing consumer willingness to pay in the sense that it generates more transactional surplus that the firm may appropriate as profits. See id. at 546-47 (giving examples of such cost-reducing integrations); SCHERER \& ROSS, supra note 186, at 525, 530 ("Integration improves the efficiency of downstream input choices.").

209 This knowledge may or may not be transferable. See PENROSE \& PENROSE, supra note 163 (discussing firm-specific knowledge). If it is transferable, then the input monopolist should be indifferent between integrating vertically itself or supplying the knowledge, along with the monopolist's other input, to some other firm for purposes of producing the downstream product. Strategic considerations, discussed immediately following this note, might, however, lead the input monopolist to produce the product itself, despite being able to share the knowledge of how to produce it with others.

${ }^{210}$ See HovenKAMP, supra note 3, at 546-47 (discussing the case of the newspaper that integrated its morning and evening edition advertising products in order to eliminate the cost of typesetting two different advertising supplements).

211 See Oliver E. Williamson, The ECONOMic Institutions of CAPitalism: Firms, MARKETS, RELATIONAL CONTRACTING (1985); HoVENKAMP, supra note 3, at 497 ("When vertical integraton eliminates transactions with a monopolist, the result can be higher profits and lower prices for consumers[.]").

212 The result is the famous "bilateral monopoly" cooperative bargaining game for which there is no guaranteed solution. See LAYCOCK, supra note 123, at 414 (discussing bilateral monopoly); HoVENKAMP, supra note 3, at 494 n.19. 
pay a tax to some other input monopolist in the supply chain. ${ }^{213}$

Both the product improvement rationale for vertical integration and the strategic defense rationale are probably good for the economy. The first is the heart of innovation and technology-driven growth, and the second ensures that the holdup problems incident to clashes between monopolists at different levels of the supply chain do not disrupt markets. ${ }^{214}$ But strategic defense also has a dark side. For if adversaries of the input monopolist produce inputs that render the finished product better for consumers than what the input monopolist is able to offer, then the input monopolist's insistence on making the product itself, to the exclusion of the adversaries, results in a worse product for consumers. ${ }^{215}$ So long as the input controlled by the input monopolist is of greater importance in the finished product than what any adversary offers, the input monopolist can exclude adversaries from the market, for faced with the choice between a product containing the input monopolist's input but not the adversary's, and a production lacking the input monopolist's input, but containing the adversaries, consumers will choose the input monopolist's product. ${ }^{216}$ But the consumers will end up worse off than they would be were the input monopolist to supply the adversary and enable a product containing both the input monopolist's input and the adversary's superior input to reach consumers. ${ }^{217}$

Probably the starkest example of this sort of dark strategy is the negative tie immortalized in Lorain Journal Co. v. United States. ${ }^{218}$ In that case, a newspaper, which supplied local retailers the essential input of local newspaper advertising insisted that any retailer buying ads in the newspaper not buy ads on the local radio station. ${ }^{219}$ The product that the Lorain Journal

\footnotetext{
${ }^{213}$ See SCHERER \& ROSS, supra note 186, at 530 (observing that the mere threat of integration may be sufficient to keep adversaries in check); HoVENKAMP, supra note 3, at 399 ("The monopolist might integrate vertically in order to eliminate a downstream firm's market power.").

${ }^{214}$ See SCHERER \& ROSS, supra note 186, at 521-22 (observing that "vertical integration can break bilateral monopoly stalemates and increase output"); PENROSE \& PENROSE, supra note 163 (discussing the importance of firm-specific knowledge); David J. Teece, Profiting from Technological Innovation: Implications for Integration, Collaboration, Licensing and Public Policy, 22 RES. POL'y 112, 290 (1993) (discussing conditions under which innovation and vertical integration are necessarily connected).

215 See John J. Flynn, Antitrust Policy, Innovation Efficiencies, and the Suppression of Technology Symposium: Antitrust and the Suppression of Technology in the Unites States and Europe: Is There a Remedy, 66 ANTITRUST L.J. 487, 502-3 (1998) (observing that AT\&T suppressed MCI's innovative long-distance technology by integrating its longdistance services with its monopolized local-calling services).

216 See id.

${ }^{217}$ See id.

${ }^{218}$ Lorain Journal Co. v. United States, 342 U.S. 143 (Supreme Court 1951).

${ }^{219}$ See id. at $149-53$.
} 
insisted on selling to retailers was in effect local newspaper advertising plus a prohibition on doing business with the radio station. Clearly this was an inferior product relative to one in which a retailer might buy both newspaper and radio advertising. ${ }^{220}$ But retailers still preferred to purchase this product because they viewed radio advertising as of only supplemental value in relation to newspaper advertising. ${ }^{221}$ The Lorain Journal had in fact tried and failed to start its own radio station and clearly feared that radio advertising might come to be seen by advertisers as more than supplemental, placing Lorain Journal in the position of having to share advertising profits with radio stations for fear of losing customers to them. ${ }^{222}$

The prohibition on radio advertising in Lorain Journal is a classic example of a firm refusing to supply an input to a competitor in order to maintain a strategic advantage at the expense of product quality, albeit an example somewhat obscured by a technological context for which the components at issue - newspaper advertising and radio advertising — can be combined by consumers themselves and so do not need to be assembled and packaged prior to sale. ${ }^{223}$ Retailers effectively purchased bundles of newspaper and radio advertising that they assembled themselves. ${ }^{224}$ Because retailers viewed radio advertising as supplemental, they would only purchase radio advertising in combination with newspaper advertising, making newspaper advertising an essential input into the newspaper-plus-radioadvertising bundles that retailers purchased. ${ }^{225}$ By refusing to sell newspaper advertising to retailers who purchased radio advertising, Lorain Journal effectively denied an essential input to the bundle to which radio advertising contributed, driving the bundle, and thereby the radio station that could sell exclusively through that bundle, from the market. ${ }^{226}$

\footnotetext{
${ }^{220}$ See id. at 153 ("Numerous Lorain advertisers wished to supplement their local newspaper advertising with local radio advertising but could not afford to discontinue their newspaper advertising in order to use the radio.").

${ }^{221}$ See id.

${ }^{222}$ See id. at 146 (stating that "without success, [Lorain Journal] sought a license to establish and operate a radio broadcasting station in Lorain").

223 See HovenKAMP, supra note 3, at 537-39 (discussing the phenomenon of product separateness in the tying context).

${ }^{224}$ See Lorain Journal Co. v. United States, 342 U.S. at 149-53.

225 See id. at 153.

226 To see the equivalence to a refusal to supply an input to a competitor even more clearly, imagine that Lorain Journal were to monopolize eraser-less pencils and the radio station to sell eraser-tipped pencils. Lorain Journal could have achieved the same outcome as it did in Lorain Journal only by refusing to supply pencils to the radio station, making it impossible for the station to manufacture eraser-tipped pencils and sell that superior product on to consumers. The result would then have been that only Lorain Journal's eraser-less pencils would have been sold on the market, even though they are inferior to eraser-tipped pencils.
} 


\section{b. Antitrust Regulates Only Vertical Integration}

The antitrust laws have generally permitted exercises of power aimed only at extracting a money payment from buyers in the direct sense of refusing to supply the input unless money is paid. This is the rule in U.S. antitrust that the charging of high prices, by itself, is not enough to violate the antitrust laws. ${ }^{227}$ The antitrust laws have, by contrast, traditionally frowned upon all attempts to integrate downstream. ${ }^{228}$ Firms that acquire power over an input have traditionally been expected to stay in their input market, selling at whatever price they wish but not integrating downstream to compete in the markets to which they supply inputs. ${ }^{229}$ If taken seriously, this policy would of course have been unworkable. All inputs are agglomerations of other inputs and so all input monopolists are already integrated vertically to some extent. ${ }^{230}$ A rule banning all vertical integration would force each firm that has monopoly control over any input to engage in the potentially infinite task of divesting itself of every component of that input that can be supplied by others. ${ }^{231}$ The owner of all the gold in the world would need to divest its mining and distribution assets of course, as well as its customer service operations, and even its management, as these too are inputs into the product the firm sells to consumers. ${ }^{232}$

To make the rule against downstream integration workable, the courts implemented it only in part. They refrained from molesting vertical integration where the integrated components are physically connected to each other in the finished product sold to consumers. ${ }^{233}$ So for example a

Consumers would still have purchased this inferior product, and not the eraser tips sold separately by the radio station because a pencil is more valuable than a pencil-less eraser tip and the radio station would have been unable to obtain the pencils it would need to manufacture and sell eraser-tipped pencils. The refusal to supply pencils to the radio station here would substitute for the refusal to sell newspaper advertising to radio advertisers because eraser-tipped pencils cannot be assembled by consumers on their own and so in the case of pencils the refusal must be directed at a competitor who assembles the compound product for consumers rather than at consumers themselves.

227 See HovenKAMP, supra note 3, at 356-58 (concluding that bad conduct, as opposed to the mere charging of a high price, is necessary for a violation of the antitrust laws).

228 See id. at 496 ("In its earlier history Antitrust policy was hostile toward vertical integration, particularly when one of the market levels involved was subject to monopoly."). ${ }^{229}$ See id.

${ }^{230}$ See id. at 489 (stating that "all firms are vertically integrated to some degree").

${ }^{231}$ For the significance of the distinction between monopolized inputs and inputs that can be supplied by others, see supra Section III.B.1.a.

${ }^{232}$ See Demsetz, supra note 41, at 2 (treating management as an input).

233 Thus "technological tying" and the tying of two products that are "not separate" were immune to antitrust action except in rare cases. See HovENKAMP, supra note 3, at 407-10, 535-37 (discussing the separate products requirement in tying, technological tying and 
portable stereo for which the batteries are hardwired into the system and inaccessible to consumers would attract no antitrust scrutiny, even if this design would place competing battery makers at a competitive disadvantage and even if the stereo maker were to terminate a prior practice of purchasing its hardwired batteries from an outside supplier and to start making the batteries in-house instead. Such a decision might amount to denial to the outside supplier of batteries of access to the essential input of stereos for which to sell the batteries, but the courts would not intervene. ${ }^{234}$ By contrast, the integration of components that are not physically connected into a single product, such as sale of a stereo designed to take replaceable batteries along with starter sets of the batteries manufactured by the same company, could run afoul of the antitrust laws, particularly if the company had initially sourced the starter batteries included in the bundle from an outside supplier. Sale of the stereo in combination with the batteries then might constitute illegal tying, or a termination of a prior profitable course of dealing with the outside battery supplier and therefore an illegal "refusal to deal."235 Vertical

predatory product innovation).

234 That is, like the example of Lorain Journal discussed above, the fact that the stereos and batteries are sold separately to consumers, who assemble the finished stereo-plus-batteries product themselves, obscures the fact that the battery makers and the stereo makers are in a vertical relationship and indeed that, so long as the batteries are tailored for use in stereos, the stereos are an essential input, from the perspective of battery markers, into the finished product to which they contribute the battery component. See supra note 226 and accompanying text.

235 The fact that the two products are physically separable opens the door to satisfaction of the separate products requirement for a tying claim, although a welter of confused subsidiary rules, such as whether the tying product (the stereo) is normally sold separately from the tied product or should be but is new enough to consumers that tying them together would help consumers understand the product, could block a claim. See HoVENKAMP, supra note 3, at 537-39 (discussing the "competitive market test" and the "new products" doctrine for product separateness). The requirements of a certain level of power in both the tying and tied product markets would also need to be satisfied for a tying claim to succeed. See id. at 51718 (providing the judicial test for tying). Independently of any tying claim, a "refusal to deal" claim would lie were the inclusion of the stereo maker's batteries to constitute a termination of a prior profitable course of dealing and, under older precedent, potentially even if it were not. See id. at 382-87 (discussing the Aspen Skiing exception to the no duty to deal rule). But this would be true only if the court could conceive of stereos and batteries as separate products, such that the stereo maker's refusal to open the stereo to batteries made by others would appear to be a refusal to supply a separate but essential input to battery makers rather than merely a refusal to tear apart a unitary product and hive off its shards for the benefit of competitors. See Verizon Commc'ns Inc. v. Law Offices of Curtis V. Trinko, 540 U.S. 398, 410 (U.S. 2004) (concluding that Verizon has no duty to deal with competing phone service providers in part because Verizon's product as a technical matter is unitary: supplying network services to competitors would require the creation of "unbundled elements" that "exist only deep within the bowels of Verizon .... New systems must be designed and 
integration through the purchase of entire companies was also more or less banned. ${ }^{236}$

The courts also showed a bias in favor of formally unitary business organizations in the sense of those held together by employment relationships and the laws of agency, rather than merely contracts. A firm that integrates vertically by hiring employees to carry out services that the firm had previously obtained from independent contractors would not violate the antitrust laws, even if in cutting off the independent contractors the firm denies them an essential input, namely the operations of the firm to which the contractors had contributed their services. ${ }^{237}$ The firm qua human unit is seen as necessarily integrated, in the same way that all the parts of a mechanical or electrical device are seen as necessarily integrated. But if the laborers are autonomous robots, rather than human beings, then the same act of integrating vertically by generating the robot services in house could run afoul of the antitrust laws for the same reasons that a firm that packages its own starter batteries with its stereos, instead of sourcing them from the market, could run afoul of the antitrust laws. As machines, the robots would appear more as separable components than as part of a necessarily-integrated whole. $^{238}$

Starting in the 1960s, the Chicago School exposed the arbitrariness of these rules. Blocking vertical mergers did not prevent vertical integration, argued Chicago, but it did arbitrarily force firms to reinvent the wheel every time they wanted to integrate vertically. ${ }^{239}$ If firms failed to reinvent a wheel that was as good as the one they could have acquired through vertical merger, the result was a poorer product and harm to consumers. ${ }^{240}$ Similarly, blocking only vertical integration involving physically separate components seemed to reflect an arbitrary bias against services and in favor of goods, and a failure to understand that the product extends far beyond any physical object that may exchange hands. Antitrust had taken a particularly hard line against

\footnotetext{
implemented simply to make that access possible").

${ }^{236}$ See HovenKAMP, supra note 3, at 505 ("Historically, vertical mergers did not fare well under the antitrust laws.").

${ }^{237}$ See id. at 399, 541 (discussing Paschall v. Kansas City Star, in which the Eighth Circuit held that a newspaper's decision to take its delivery services in house, cutting off independent contractor deliverer, was no antitrust violation and observing that "[i] $\mathrm{f}$ only labor is involved, then a single product conclusion seems inescapable: the defendant is merely terminating a contract with an independent entity and substituting an employee").

${ }^{238}$ See supra note 235 and accompanying text.

239 See Robert H Bork, The Antitrust PARAdOX: A POliCy AT WAR with ItSelf 227 (1978) ("The only difference between vertical merger and vertical growth is that in a specific situation at a particular moment one of the other will be the lower-cost way of achieving the efficiencies of integration.").

${ }^{240}$ See id.
} 
restrictions placed by manufacturers on the manner and price at which retailers sold their products. ${ }^{241}$ But the manner in which a retailer displays a product, the level of customer service provided, and the price charged are all a part of the overall product experience of the buyer, along with the physical object itself. ${ }^{242}$ A manufacturer that uses restrictions on retailers to improve display and customer service may improve the product just as much as does a manufacturer that adds a new screw inside the product's casing. ${ }^{243}$ To these, Chicago might have done well to add that condemning only firms that change course and integrate vertically only after trying first to supply inputs rather than finished products to the market serves only to encourage firms to vertically integrate from the start and to discourage firms from experimenting with vertical disintegration, the opposite of the result that antitrust seems to want to achieve in frowning upon vertical integration.

Chicago's critiques did not really succeed at undermining the bias in favor of physically-integrated products, or in favor of products that are integrated from the start. ${ }^{244}$ But it did eliminate the rule against vertical mergers and the heavy-handed treatment of restrictions placed by manufacturers on retailers. ${ }^{245}$ More importantly, it shifted antitrust's focus away from the unworkable goal of banning all vertical integrations toward the problem of distinguishing integrations that are good for consumers from those that are bad for consumers. ${ }^{246}$ The rule that has emerged, at least outside the context of physically-integrated or first-integrated products, is that integrations that improves the quality of the product offered to consumers are licit and integrations that reduce the quality of the products offered by others without improving the defendant's own product are illicit. ${ }^{247}$ So firms that integrate vertically to improve their products are safe, and firms that integrate vertically to head off competitors, when doing so

\footnotetext{
${ }^{241}$ See GAVIL ET AL., supra note 20, at 902 (observing that "[a]t times, such practices have faced very harsh treatment, even per se illegality").

${ }^{242}$ See BORK, supra note 239, at 290-91, 318-19 ("[W] services or gratifications, the product differentiation created by . . promotion becomes indistinguishable from the physical differentiation of products").

${ }^{243}$ See id.

244 The law of tying still requires a showing that the products are separate, and the law of refusals to deal has, if anything, come to place even more stress on the need for a termination of a prior dealing as a condition for liability. See HovENKAMP, supra note 3, at 382-87, 537. 245 See id. at 580 (noting that the rule of reason now applies to all vertical intrabrand restraints); GAVIL ET AL., supra note 20, at 882 (noting that "[b]y 1989" vertical mergers wre "not an unlawful or even suspect category under the antitrust law" at least in the eyes of one court).

${ }^{246}$ See Muris, supra note 91, at 859-60 (observing that all of antitrust law had ocnverged on a rule of reason approach to determining liability, one that is focused on effects).

${ }^{247}$ See Woodcock, supra note 150, at 2309-13.
} 
blocks consumers from accessing a superior product, are liable. ${ }^{248}$ The trouble with this approach is that it puts courts in the position of having to decide what is a product improvement and what is not. ${ }^{249}$ Ever wary of having to make substantive decisions of any kind, courts have responded by trying to let consumers decide for them. ${ }^{250}$ They do this by calling upon economists to act as mediums, predicting consumer preferences for the products involved, a process that they characterize as the measurement of harm to consumer welfare. ${ }^{251}$ The result has been a bonanza for economists and costly litigation that plaintiffs almost never win. ${ }^{252}$

\section{The State}

Public law mirrors antitrust law in that it generally permits state exercises of power aimed only at extracting a payment from buyers in the direct sense of refusing to supply the security input unless money is paid. That is taxation, which is expressly authorized by the U.S. Constitution and enforceable with imprisonment under the criminal law. ${ }^{253}$ The Constitution imposes very few limitations on the basic power of the government to tax, just as antitrust imposes almost no restrictions on the power of the monopolist to choose the price it wishes to charge to consumers. ${ }^{254}$ But like antitrust, public law does regulate exercises of power that go beyond the basic demand of a money payment from the immediate purchaser of the security input. ${ }^{255}$

As in the business context to which antitrust is applied, in the government context such exercises of power are associated with vertical integration by

\footnotetext{
${ }^{248}$ See id.

${ }^{249}$ See HoVENKAMP, supra note 3, at 407-9 (recognizing that deciding whether an innovation is "predatory" depends on whether the new product is "superior" or "inferior").

${ }^{250}$ See id. at 407 (pointing out that "whether a new product is 'superior' or 'inferior' to an old product is entirely a matter of consumer preference.").

${ }^{251}$ See Stucke, supra note 92, at 1440-42.

${ }^{252}$ See id. at $1460-68$.

${ }^{253}$ See Stephen W. Mazza \& Tracy A. Kaye, Restricting the Legislative Power to Tax in the United States, 54 AM. J. COMP. L. 641, 641-44 (2006) ("The Government's authority to impose taxes is one of its most pervasive and fundamental powers. . . As a result, constitutional law has played a relatively minor role in the development of tax laws in the United States."); Ray A. Knight \& Lee G. Knight, Criminal Tax Fraud: An Analytical Review, 57 Mo. L. REV. 175, 175 (1992) (giving examples of criminal convictions for tax fraud).

254 See License Tax Cases, 72 U.S. 462, 471 (Supreme Court 1866) ("[T]he power of Congress to tax is a very extensive power. It is given in the Constitution, with only one exception and only two qualifications. . . . Thus limited, and thus only, it reaches every subject, and may be exercised at discretion."). For the lack of antitrust restrictions on pricing by a monopolist, see supra Section III.B.1.b.

${ }^{255}$ See supra Section III.B.1.b.
} 
the government into downstream markets. In the case of the government, the downstream market is the entire economy, the totality of the means of production. Like any business firm, government is of course always vertically integrated to some extent. ${ }^{256}$ Indeed, the security input itself can only really be understood as a compound input, made up of weapons, security forces and some sort of legitimating ideology that holds them together and causes them to submit to the direction of the leaders or the state. ${ }^{257}$ It follows that the security sold by the state is the product of vertical integration by the state into, among other things, the production of security forces, ideology, and often weapons as well. ${ }^{258}$ The problem of power exercise posed by the vertical integration of the state is the same as that posed by the vertical integration of business: to determine when the state may in fact integrate vertically and to define the circumstances under which the state can deny access to essential inputs to those who would compete with the state's vertically-integrated operations. ${ }^{259}$

The historical approach of public law was to impose no limits on vertical integration at all. Public law permitted the state vertically to integrate so totally that the state and the economy amounted to a single vertically integrated organization, one that was free to deny security to anyone who sought to compete with it in any downstream market. This was the approach taken by states in the ancient world stretching forward in time up through the middle ages and in some cases very nearly up until the modern age. ${ }^{260}$ To choose an example at random, consider the medieval European seignory. Although in theory a distant king was the ultimate authority, the lord was for all intents and purposes the state and controlled the security input thanks to

${ }^{256}$ See supra Section III.A.1.

257 According to Weber, the only really essential input into the force monopoly is the legitimation of the ruler, which allows him to command at least some people to carry out violence on his behalf. See 1 WEBER, supra note 73, at 53 ("The existence of domination turns only on the actual presence of one person successfully issuing orders to others; it does not necessarily imply either the existence of an administrative staff or, for that matter, of an organization. It is, however, uncommon to find it unrelated to at least one of these.").

${ }^{258}$ See id. at 53-54.

259 See supra Section III.B.1.

260 See CAENEGEM, supra note 24, at 36 (describing the "patrimonial conception of the kingdom as family heirloom" that prevailed after the fall of the Roman Empire as well as the institution of the medieval seignory, which "became a mini-state and the landowner . . . a lord or ruler, who governed the peasants, free and unfree living on his land, to the exclusion of the normal bearers of public authority" as "widespread" until the rise of the modern state); Toby A. H Wilkinson, The Rise And FAll of AnCIENT EgyPT 46, 58 (2013) (describing Ancient Egyptian pharaohs as owners of their kingdoms, which were operated for the pharaoh's benefit, rather than for that of the people); BENJAMIN R FOSTER \& KAREN Polinger Foster, Civilizations of ANCIENT IRAQ 67-68 (2011) (describing Third Dynasty Ur as essentially a centrally planned economy). 
the combination of a legitimizing grant of authority by the king and the possession of horses, arms, and armor. ${ }^{261}$ The lord also exercised centralized control over all inputs into the production of anything within the geographic area into which the lord supplied security. Thus the lord controlled not only the land, but also all ovens, winepresses, looms for weaving, mills, roads, bridges, and the like. ${ }^{262}$ And the lord also owned the people who worked the land and the various tools of petty manufacture. ${ }^{263}$ This meant that public law imposed no limitation on the ability of the lord to deny the people access to the security input, just as property law today gives the owner the right to dispose of the owned object as the owner sees fit. ${ }^{264}$ The lord could kill, or at least beat, whomever he wished whenever he wished subject to no outside

261 See CAENEGEM, supra note 24, at 62 (noting that while knights often held their seignory "in fief from their suzerians" or, as in pre-Conquest England, pursuant to "royal grants of jurisdiction," their "authority over a submissive peasantry must have seemed natural in a society dominated by a class of landowners and warriors, who were hardly kept in check by the remote and weak kings of the period").

${ }^{262}$ See DUPLESSIS, supra note 24, at 15, 17 (describing the "seigniorial monopolies such as ovens, wine-presses, and mills" and also the lord's ownership, and right to tax for use, of "forests, fishponds, and streams").

263 See Paul VinOgRAdOFF, Villainage in England: EsSAYS IN ENGLish MEdiaEVAL HISTORY 287 (1892) ("The tenants mind the lord's plows, construct houses and booths for him, repair hedges and dykes, work in vineyards, wash and sheer the sheep, etc."). Ownership is perhaps too strong a word to use for the relationship between the lord and the serfs, but the legal relationship had many of the attributes that one would expect to find in an ownership relation. See Thomas D. Morris, Villeinage. . . as It Existed in England, Reflects but Little Light on Our Subject: The Problem of the Sources of Southern Slave Law, 32 AM. J. LEGAL HIST. 95, 106-7 (1988) (arguing that true slavery consists in the notion that the person is properly and therefore governed entirely by the law of property alone); SIR William Searle Holdsworth, A History of English Law: (1066-1485) The MEDiAEVAL COMMON LAW 495 (1923) ("[V]illeinage is the relation of a person to his Lord: it is not, like slavery, a condition of right less nests as against the world at large."). In particular, the serfs, called "villeins" in English law, could not travel without the lord's permission, were obliged to work according to the arbitrary and unpredetermined direction of the lord, could be sold, could have their property seized arbitrarily by the lord, and could also be arbitrarily corporally punished by the lord. See Morris, supra, at 127-30; The Origin and History of Villein Tenure Note, 2 LAW COACH 46, 47 (1921-1922). But arbitrary killing or maiming were prohibited, as was rape, and a serf could own property, subject, however, to the lord's right of seizure, and could bring lawsuits against anyone but the lord, giving the serf a level of agency under the law that living property, such as livestock, lacks. See Morris, supra, at 127-30. These rights would not, however, have limited the power of the lord to direct the labor of the serf in exchange for no more than a subsistence wage, as if the serf were an automaton, or livestock.

${ }^{264}$ See Daniel Martin, Dispersing the Cloud: Reaffirming the Right to Destroy in a New Era of Digital Property The Washington and Lee Law Alumni Association Student Notes Colloquium, 74 WASH. \& LEE L. REV. 467, 474 (2017) (discussing the right of the owner arbitrarily to dispose of or otherwise destroy property). 
review whatsoever. ${ }^{265}$ The lord's right to refuse to deal in security was, in other words, more or less absolute. This made the peasantry akin to livestock, and the lord fed them and used them for labor in the way that he fed his horses and used them for labor. The only consumer in this world was the lord himself, and so he paid himself whatever tax he wished in exchange for the bounty that he produced for himself through this fully integrated economic organization. ${ }^{266}$

Anyone who wished to compete with the lord to produce anything, meaning anyone who wished to act as a free economic agent in relation to the lord, was immediately denied access to the security input controlled by the lord, not to mention all the other inputs, and beaten, starved, or ejected from the land. ${ }^{267}$ Firms today often do have the right to deny inputs entirely to competing firms, but this never results in anything akin to the slavery we see in the premodern world only because the inputs firms deny each other are things like widgets, not security, and so the victims of these denials always have alternatives to obedience, such as closing up shop and investing elsewhere. ${ }^{268}$ By contrast, the only alternative to denial of the security input is physical punishment or death, and as that is not an alternative for most, the result is the abdication of control over the body to the force monopolist, and a subjection that goes far beyond the mere loss of profits that characterizes a refusal to deal in an industrial input of some sort.

This was the most complete form of vertical integration of the state, and existed to varying degrees throughout the pre-modern period. ${ }^{269}$ As the state progressed toward modernity, the first and most important way in which the state's vertical integration broke down was through the emancipation of labor, the slow accretion of legal rights in favor of the peasantry. ${ }^{270}$ These rights reduced the ability of the lord to exercise power by limiting the

265 See HOLDSWORTH, supra note 263, at 493-94 ("The Lord could imprison and beat his villein; and in practice this may have led to a good deal of oppression in particular cases. But against grosser forms of personal violence he was protected by the criminal law."); VINOGRADOFF, supra note 263, at 45-46.

266 See HOLDSWORTH, supra note 263, at 495 ("As against the lord who is seised of him the villein has no property[.]').

267 See id.

268 See HovENKAMP, supra note 3, at 381-88 (discussing the antitrust law right to refuse to deal).

269 See DuPLESSIS, supra note 24, at 15 (noting that not all land in medieval Europe was subject to seigniorial right and "[s]ome property was 'allodial,' freely owned by those who inhabited and farmed it").

${ }^{270}$ See VINOGRADOFF, supra note 263, at 43 ("There is no doubt that great landmarks in the course of social development are set by the three modes hitherto employed of organizing human labor: using the working man [1] as a chattel at will, [2] as a subordinate whose duties are fixed by custom, [3] as a free agent bound by contract."). 
circumstances according to which the lord was permitted to deny the security input to the peasantry. For example, the serf went from owing an obligation to do whatever work the lord directed him to do, at whatever time, to owing only an obligation to work on the lord's lands for a certain number of days per week, the rest of the peasant's time being placed under the peasant's own control. ${ }^{271}$ Regardless of the substance of these new rights, the net effect was to make impossible the total denial of the security input that is a necessary incident to ownership, and so to convert the peasant from a slave into a rightsbearing person. ${ }^{272}$

Every new limitation on the ability of the lord to deny access to security gave the peasant bargaining power with respect to the terms of his employment. ${ }^{273}$ No longer could the lord dole out the minimum required for subsistence and keep the rest. Instead, the lord had to pay workers some part of the surplus that they generated in order to secure their effort. ${ }^{274}$ Peasants traded these surpluses for goods produced by the manor, from bread to wine, or to purchase freeholds from the lord during economic emergencies. ${ }^{275} \mathrm{In}$ this way what had started out as a fully-integrated unitary economic enterprise run for the consumption benefit of the lord became a true economy in which the lord hired labor, sold the output of the manor to consumers, and faced competition from freeholders. ${ }^{276}$ The process of the vertical disintegration of the state from the means of production had begun.

But it was not until the $19^{\text {th }}$ century that two additional limitations on the power of the state that are key to modernity entered public law. The first was the decline of restrictions on the lines of business in which a person could engage. ${ }^{277}$ While the proliferation of freeholds brought competition in

\footnotetext{
${ }^{271}$ See R. H. Hilton, The DeCline OF SERFDOM In MEDIEVAl EnGLAND (2016); Jean-Pierre Devroey, Men and Women in Early Medieval Serfdom: The Ninth-Century North Frankish Evidence, PAST \& PRESENT 3, 6-7 (2000) (stating that "slaves were gradually protected against the cruelty of their master").

${ }^{272}$ See VINOGRADOFF, supra note 263, at 43.

${ }^{273}$ See id.

${ }^{274}$ See DUPLESSIS, supra note 24, at 16 ("[F]rom the 12 th century onwards, lords had faced stiffening peasant resistance .... In the circumstances, many lords had granted or sold freedom to slaves and serfs, exchanged ["commuted"] labor services for payments in cash or kind, and leased their demesnes to cultivators.").

275 See id.

${ }^{276}$ See id.

277 See JOEL MOKYR, THE ENLIGHTENED ECONOMY: An ECONOMIC HistORY OF BRITAIN, 1700-1850 396-97 (2009) (describing restrictions on business that eroded over the course of the 19th century in Britain, including import and export restrictions, the need for an act of Parliament to undertake any large-scale capital project, and the "Statute of Apprentices and Artificers ... which constrained workers in many occupations to a formal apprenticeship before they could be employed in their trade").
} 
agriculture, that did not necessarily reduce the profits of the lord, who could still extract as much as he wanted through the right of taxation. ${ }^{278}$ In the early modern era, however, taxation was difficult to administer, and so the lord was to some extent limited in the amount he could extract from agricultural competitors in exchange for the lord's provision of the security input. ${ }^{279}$ But by retaining control over the production of manufactures and then charging high prices for them to consumers, or by using the provision of monopoly privileges to others as a currency with which to pay debts (the recipient in effect enjoying the taxes that the state could have extracted if the state had continue to run the business itself), the lord could continue to extract full profits from manufacturing. ${ }^{280}$

The rise of economic rights in the $19^{\text {th }}$ century put an end to these restrictions on business activity at just about the same time as states were becoming sophisticated enough to extract direct taxes from businesses and consumers. ${ }^{281}$ Curiously, no general right to engage in business ever made its way into public law, at least U.S. public law, in explicit form. ${ }^{282}$ Instead, the right to engage in any business was reflected in a gradual knocking down of restrictions on business conduct throughout the $19^{\text {th }}$ century. ${ }^{283}$ Licensing rules and monopoly privileges in many business lines were eliminated. ${ }^{284}$

\footnotetext{
278 See DUPLESSIS, supra note 24, at 22-23 (discussing the various means by which lords taxed their tenants in the early modern period).

279 See MOKYR, supra note 277, at 393 ("The British state [in the premodern period] was wedded to mercantilist principles which were in large part rent-seeking in nature. One way of thinking about the mercantilist state is to realize that it was a mutually beneficial alliance of the fiscal needs of the state and special interests seeking special considerations and advantages at the expense of their competitors or the consuming public at large. These interests deployed state power to secure benefits, many of which were exclusionary rents, in exchange for revenues needed by the government, largely for military purposes. Monopoly profits were easier to tax, and thus both sides gained, but at the expense of the economy at large.").

${ }^{280}$ See id. As the modern age approached, it was, more accurately, the king, rather than the lords, who could continue to tax, as kings clawed power back from their vassals. See CAENEGEM, supra note 24, at 72.

281 See MOKYR, supra note 277, at 393-400.

${ }^{282}$ See Louis Henkin, Economic Rights under the United States Constitution, 32 CoLUM. J. TRANSNAT'L L. 97, 98 (1994) ("Economic rights . . . are hardly mentioned in the U.S. Constitution, yet [they] flourish in the United States today in significant measure.").

283 See William J. Novak, Public Economy and the Well-Ordered Market: Law and Economic Regulation in 19th-Century America, 18 LAW \& SOC. INQUIRY 1, 30-31 (1993) (discussing the rise of laissez faire thinking in the United States after 1875).Such a knocking-down was required even in the United States, despite its founding on Enlightenment principles that included freedom of enterprise. See id. at 11-18 (listing the numerous licensing and related restrictions on entrepreneurship that existed in the United States before 1860).

${ }^{284}$ See MORTON J. HORWITZ, The Transformation OF AMERICAN LAW, 1780-1860 134 (1977) (discussing the demise of the notion that corporate chartering implied monopoly
} 
Access to business forms, such as the corporate form, needed to facilitate entrepreneurial activity was regularized and thrown open to all. ${ }^{285}$ But because the state's power to tax grew at the same time, the arrival of these economic rights would not in itself have prevented the state from continuing to extract the maximum profits from the economy in exchange for provision of the security input. ${ }^{286}$ If the tax system is effective enough, it makes no difference to the state whether it extracts profits by charging high taxes or by running downstream businesses and charging high prices for their products. ${ }^{287}$ A competitive market of bakers would still be forced to render to the state as much profit as it had extracted through the monopoly baking privilege, only now the profits would be paid as business taxes. ${ }^{288}$

The solution was the second limitation on the state's exercise of power: democracy. ${ }^{289}$ Here public law diverges markedly from antitrust law in its approach to the exercise of power. Public law, recall, like antitrust law, imposes no formal limitations on the price the state can charge, in the form of taxation, for provision of the security input. ${ }^{290}$ But democracy, which gives those who consume that input a say in the governance of the state, gives consumers an effective check on the level of those prices, just as consumers in a consumer cooperative check the ability of the firm to charge them high prices. ${ }^{291}$ The transition from monarchy to democracy is the state's transition from for-profit seller of security to cooperative seller of security. ${ }^{292}$ As a

rights in the 1837 Charles River Bridge case in the United States); Novak, supra note 283, at 27 ("Dissent crept into judicial deference to local market regulations . . . in the years immediately preceding the Civil War.").

285 See HoRWITZ, supra note 182, at 77-79 (discussing the rise of "general incorporation" statutes that permitted anyone to start a corporation and the demise of the ultra vires doctrine that had limited the business purposes to which a corporation could be put).

286 See Richard BonNey, ThE RISE OF THE FiscAL STATE IN EUROPE, C. 1200-1815 56 (2004) (charting the rise of tax receipts into the 19th century in England).

${ }^{287}$ Cf. MOKYR, supra note 277, at 393.

${ }^{288} \mathrm{Cf}$. id.

289 See Christopher Hobson, THE Rise of DEMOCRACY: Revolution, WAR AND TRANSFORMATIONS IN INTERNATIONAL POLITICS SINCE 1776 106-39 (2015) (tracing the rise of democracy across the 19th century).

${ }^{290}$ See supra text accompanying note 254.

${ }^{291}$ See HENRY HANSMANN, THE OWNERSHIP OF ENTERPRISE 169-70 (1996) ("By aligning the firm's interests with those of its customers, cooperatives can avoid . . . the costs of monopoly[.]").

292 This is well illustrated by the transformation of the post office from a royal-granted monopoly charging high prices for postage before the American Revolution to a monopoly that subsidized the delivery of newspapers for purposes of maintaining an informed public after the American Revolution. See Anuj C. Desai, The Transformation of Statutes into Constitutional Law: How Early Post Office Policy Shaped Modern First Amendment Doctrine, 58 Hastings L.J. 671, 678-84 (2006-2007). 
result, in a democracy, government generally does not extract the maximum possible profits from consumers in the form of taxes, and, what is more, the profits that government does extract are not carried off by a king or a lord operating as a rapacious owner, but rather reinvested in improving the quality of the security input sold to the public or otherwise in state-run projects viewed by the public as efficient and effective. ${ }^{293}$

Democracy has not only served as a check on the power of the state to charge high prices through taxation, but also on the state's power to integrate vertically. That power, recall, is already limited by the implicit right to engage in the business of one's choosing, which effectively prevents the state from denying access to the security input to downstream competitors. ${ }^{294}$ Democracy has, however, tended to go further, withdrawing the state from the provision of almost all goods downstream of security, save some infrastructural items, such as highways, schools, and social insurance, and regulatory goods, such as oversight of environmental safety. ${ }^{295}$ It is in the ebb and flow of state engagement in business that one sees in state practice the closest thing to antitrust's contemporary rule of reason, with its focus on allowing vertical integration that benefits consumers and avoiding vertical integration that harms them. ${ }^{296}$ Similarly, the security monopolist integrates downstream when the public sees such integration as good for the public and

293 Indeed, any use of government revenues for consumption purposes by government officials, understood as activities that are not essential to carrying out government business, is viewed in a democracy as evidence of corruption, as is any attempt to raise the price charged to consumers in exchange for government services, otherwise known as the acceptance of bribes. See Henning, supra note 26, at 802. In a monarchy, the same behavior funds the conspicuous consumption of the king. See BONNEY, supra note 286, at 21 (describing the medieval English monarchy as a "domain state" for which "there was no proper notion of an inalienable patrimony").

${ }^{294}$ See supra text accompanying note 282.

295 See DAvid A Moss, When All Else FaIls: Government As THE Ultimate RisK MANAGER 4-9 (2004) (defining the security input provided by government broadly to include three types: security for business, encompassing everything from a national currency to bankruptcy regimes, security for workers, including unemployment insurance, and "security for all," including health, safety, and environmental regulations); Moss, supra note 22, at 177-243 (detailing political struggles over the funding of public works and public education in the United States); Przemyslaw Kowalski et al., State-Owned Enterprises: Trade Effects and Policy Implications 6 (2013) (noting that in 2010 the large state-owned enterprises accounted for only $6 \%$ of global GDP). This effect of democracy is well illustrated by the royal-granted postal monopoly into the printing of newspapers prior to the American Revolution. This postal monopoly refused to deliver newspapers printed by rivals, including Benjamin Franklin. See Desai, supra note 292, at 679-80. After the American Revolution, however, the post office vertically disintegrated, exiting the printing business. See id. at 691.

${ }^{296}$ See supra Section III.B.1.b. 
sells off state-owned enterprises when the public views them as counterproductive, harmful of competition, tending to crowd out more-efficient private enterprises, and so on. ${ }^{297}$

One sees in public law, then, a picture of how the consumer cooperative form of business enterprise can be used to solve many of the problems of power exercise by a monopolist that antitrust seeks to solve, so long as the consumer members of the cooperative exercise their oversight role vigilantly. ${ }^{298}$ But most enterprises are for-profit enterprises-lender cooperatives, to use Henry Hansmann's insightful formulation-rather than consumer cooperatives, and so antitrust enforcers in most cases cannot count on consumer power over governance to limit power exercises. ${ }^{299}$ Through the application of the consumer welfare standard to govern vertical integration by input monopolists, antitrust has tried to act in the consumer interest, approving integrations when they benefit consumers and condemning them when they do not, just has the voting constituents of a consumer cooperative that also happens to be an input monopolist would presumably do for themselves. ${ }^{300}$ But antitrust's conduct requirement-its refusal to condemn the act of charging a high price in itself-limits antitrust's ability to act in the consumer interest to regulate a major category of power exercise. ${ }^{301}$

\section{THE WARREN RULE}

The rule proposed by Senator Warren that no firm be allowed to compete on its own platform is really the old mid-century rule against vertical integration by input monopolists. ${ }^{302}$ A platform is, after all, just an essential

${ }^{297}$ See Moss, supra note 22, at 177-243 (giving historical examples of this ebb and flow with respect to public works and public education).

298 See HANSMANN, supra note 291, at 169-70.

299 See id. at 12.

300 See supra Section III.B.1.b.

${ }^{301}$ See supra Section III.B.1.a.

302 The rule prohibits "a person with market power," defined to include firms having in excess of $\$ 40$ billion in revenues, from "serving as both a platform and a merchant that competes with third-party merchants" where " platform' means any technology" that "provide[s] the main interface between different ... market participants, such as . . . providers of ... services, and goods" and "allows for exchanges of at least some goods [or] services . . . that the technology does not own." See Anti-Monopoly and Competition Restoration Act of 6(b)(3)(A), 6(b)(4)(D), 6(b)(7)(E). The definition of platform as a technology that provides the "main interface between different market participants" suggests that any input that is essential to downstream markets counts as a platform (all goods are "technologies," of course). Taking into account he definition of market power employed by the proposed legislation, which encompasses traditional definitions of market power as the power profitable to raise price, but also makes revenue size a sufficient condition, the Warren rule appears to prevent large firms from integrating vertically into any market for which the firm 
input used by firms operating on the platform to create the products they sell to consumers. Preventing a firm from competing on its own platform therefore means preventing the firm from using an essential input that the firm controls to compete downstream. But using their own inputs to compete downstream is just what firms do when they integrate vertically. Like the mid-century rule, then, Sen. Warren's rule is unworkable because almost every input is itself an agglomeration of inputs, and not all of those inputs are themselves essential to downstream production. ${ }^{303}$ As a result, all input monopolists compete - through their integration into the non-monopolized inputs - on their own platforms. The faithful application of the rule would therefore require that firms strip down to their bottleneck assets, a requirement that would be inefficient, because it would not discriminate between efficient and inefficient vertical integrations, as well as impossible to execute in full, because all components are themselves components of components, ad infinitum. ${ }^{304}$

Consider Amazon, and suppose, for purposes of argument, that its Amazon.com online sales platform is an essential input into the sale of certain retail merchandise, perhaps because consumers do not view purchase of the merchandise from brick and mortar retailers as a substitute. ${ }^{305}$ The Warren rule would prevent Amazon from producing merchandise to sell on Amazon.com in competition with the merchandise sold by third-party sellers on the platform, as Amazon's sale of its own merchandise on the platform would constitute a vertical integration downstream from providing online sales platform services to the retailing of merchandise itself. ${ }^{306}$ But a faithful application of the rule could not stop there, because Amazon.com is not a unitary input, but rather a collection of a vast number of inputs, and at least one of these inputs must be essential to online retail, otherwise Amazon.com could not be said itself to be essential to online retail. It then follows that Amazon's incorporation of all the other inputs together with the essential one to make Amazon.com represents a massive vertical integration, and the Warren rule would require that Amazon disintegrate from each of those other

owns an essential input. That tracks the mid-century rule. See supra Section III.B.1.b.

${ }^{303}$ See supra Section III.B.1.b.

${ }^{304}$ See supra Section III.B.1.b.

${ }^{305}$ See Ulrich Dolata, Apple, Amazon, Google, Facebook, Microsoft: Market Concentration - Competition - Innovation Strategies, Research Contributions to Organizational Sociology and Innovation Studies, SOI Discussion Papers Nos. 2017-01, 8 (2017) (discussing Amazon's role in online retail).

306 This appears to be one of Senator Warren's goals for the legislation. See Warren, supra note 14 (calling for the breakup of Amazon's online retail platform services business and its retail merchandise business as a remedy for violation of the proposed rule that firms not compete on their own platforms). 
inputs.

If, for example, the key input into Amazon.com that makes the site essential to online retail is Amazon's network of fulfillment centers, then in hiring labor to staff those centers and creating a website to route orders through the centers, Amazon competes on its own platform, with the platform redefined now to be the fulfillment centers rather than the Amazon.com website, since the fulfillment centers are the source of the essentiality of the overall selling platform of which they are a part. ${ }^{307}$ The Warren rule would then require that Amazon stop competing in the market to supply labor services for its fulfillment centers and stop competing in the market to supply a website frontend for those centers.

But what exactly would it mean to disintegrate in labor or a web front end? Vertical disintegration is at heart consumer sovereignty: allowing consumers, rather than the input monopolist, to decide which products win in the downstream market. ${ }^{308} \mathrm{~A}$ firm that makes a downstream component itself, or even purchases one from others, and then combines it with its own input integrates vertically because in making or buying, the firm decides what components should be combined with its input, rather than leaving it to consumer to pick among the options available on the market. ${ }^{309}$

307 See Jean-François Houde et al., Economies of Density in E-Commerce: A Study of Amazon's Fulfillment Center Network, No. 23361, 6-8 (2017) (discussing Amazon's fulfullment centers).

${ }^{308}$ For consumer sovereignty and antitrust, see Neil W. Averitt \& Robert H. Lande, Consumer Sovereignty: A Unified Theory of Antitrust and Consumer Protection Law, 65 ANTITRUST L.J. 713, 713-15 (1997).

309 This definition differs from the common definition of integration, which is "unified ownership" of the firm that produces the monopolized input and a firm that produces a downstream input. See WiLliamson, supra note 211, at 163 . The instant definition of vertical integration as seller control encompasses restrictions placed on downstream firms via contract that do not fall within the traditional definition but which are increasingly important, and can be equally restrictive. See Lisa Bernstein, Beyond Relational Contracts: Social Capital and Network Governance in Procurement Contracts, 7 J. LEGAL ANALYSIS 561, 562 (2015) (observing that the supply contracts signed by "large mid-western original equipment manufacturers" do not so much create contracts as "supply relationships that" are "similar to the role that is played by firm boundaries"). It is unlikely that critics of Amazon's practice of competing on its own platform would be satisfied were Amazon to stop selling its own merchandise on Amazon.com and instead to use contracts to favor a particular thirdparty seller. Amazon already effectively shares profits with third-party sellers, because it charges them fees that are measured as a share of profits. See Vibhanshu Abhishek et al., Agency Selling or Reselling? Channel Structures in Electronic Retailing, 62 MGMT. SCI. 2259, 2260 (2015). Amazon might then alter the contractual terms that third-party sellers accept when they sell on Amazon.com to obtain a larger-than-normal share of a particular third-party seller's profits and to dictate the nature of the products that the third-party seller retails on the platform. Critics would attack such an arrangement on the ground that so long as Amazon has a special interest in a particular firm, as it would were it to impose different 
For consumers to be sovereign, however, they must face an unbiased selection, and so disintegration implies a rule of nondiscrimination in the terms of sale of the monopolized input to the downstream firms who then sell to consumers. ${ }^{310}$ In markets in which Amazon does not sell its own branded products, Amazon's practice of allowing third-party sellers to retail via Amazon.com is a vertical disintegration because Amazon imposes the same fee schedule and listing rules on all sellers and otherwise allows consumers to decide which seller sells the best products, running disfavored sellers off the site by choosing not to buy from them. ${ }^{311}$ By contrast, Home Depot is vertically integrated in retail because Home Depot decides which brands to retail in its stores. ${ }^{312}$ Whether Home Depot manufacturer those brands itself

contractual profit sharing terms on a particular third-party seller, Amazon would have an incentive to favor that firm over others, harming other third-party sellers and consumers as well, who would not be able to perceive which third-party sellers are best because the sellers would be competing on an uneven playing field. The capacious definition of integration used here is consistent with the view that unified ownership is not the only path to the harms associated with integration.

That said, it is peculiar that critics of Amazon have not attacked Amazon for another practice that is closer to its practice of selling products it makes on Amazon.com and in which Amazon actually engages: Amazon's sale, as retailer, of non-Amazon-branded merchandise on its website. When Amazon sells non-Amazon-branded products on Amazon.com - the source of the familiar "sold by Amazon" label on Amazon.com product pages - the company purchases the product from a manufacturer (that copy of Blackstone's Commentaries published by Oxford University Press, for example) and then retails it on Amazon.com in competition with third-party sellers retailing the same product. See id. at 2259 (discussing Amazon's "reselling model"). This, too, is vertical integration. See infra note 313 and accompanying text. And although margins may be smaller for Amazon on goods that it retails but does not make than on goods that it makes, Amazon nevertheless has an incentive to favor goods its sells over goods sold by third parties.

${ }^{310}$ In general, scholars have tended to emphasize the importance of presenting consumers with a variety of options in order for consumers to maintain sovereignty over markets. See Averitt \& Lande, supra note 308, at 716 (stating that "that effective consumer choice requires two things: options in the marketplace, and the ability to choose freely among them"). But the non-interference of input suppliers in the determination of what options to present consumers is also important. Indeed, an excessive bias will drive firms from the market and thereby reduce the number of options available.

311 See Selling Policies and Seller Code of Conduct - Amazon Seller Central, https://sellercentral.amazon.com/gp/help/external/G1801?language=en_US (last visited Sep. 29, 2020) (imposing a set of facially neutral "policies" that third-party sellers must follow "when listing products on Amazon").

312 See Abhishek et al., supra note 309, at 2259-60 (distinguishing agency business models, such as that employed by Amazon Marketplace, from reselling models in which the seller takes title to the good and sets their prices); Suppliers and Providers - The Home Depot, https://www.homedepot.com/c/suppliers_and_providers (last visited Sep. 29, 2020) (describing the process through which a firm can submit a product to Home Depot in order to become a "merchandising supplier" to the company). 
or merely stocks products made by others is irrelevant here. What matters is that Home Depot decides which brands appear in its stores. ${ }^{313}$ It is for this reason that what critics of Amazon decry is not merely that Amazon sells its own brands along with those of third parties but that Amazon favors its own brands in advertising on the site, effectively biasing the terms of access to its site in favor of its own products. ${ }^{314}$ Amazon's favoritism of its own products is Home Depot-style product curation, but to a reduced degree.

Vertical disintegration of labor would require that Amazon give prospective laborers neutral terms of access to Amazon's fulfillment centers and then leave it to buyers - probably here Amazon's third-party sellers - to bid for their labor and in so doing to select the workers who actually end up working at the fulfillment centers in the long run. Amazon might create a system of worker profiles and reviews that third-party sellers could then use to bid to route orders through the best workers, buy slices of cleaning value from the best janitors, and so on. ${ }^{315}$ Vertical disintegration of web frontends would require that Amazon create a set of software functions-an "application programming interface" - that makers of frontends could use to interface with Amazon's fulfillment centers. ${ }^{316}$ The frontend could then sell browsing and checkout services to consumers whose preferences would then determine which frontend would win in the market.

These vertical disintegrations appear feasible when considered individually, but once one considers that this would need to be done for virtually all inputs, and not just labor or frontends, the mind reels. Consider for example, that the ratings system that Amazon might put into place to enable buyers to choose between workers is itself an input, and one that Amazon would not be permitted to provide itself, for that would constitute vertical integration. ${ }^{317}$ Amazon would therefore be required to disintegrate from worker ratings, perhaps by making data on workers available in

\footnotetext{
${ }^{313}$ See Suppliers and Providers - The Home Depot, supra note 312.

${ }^{314}$ See Jay Greene, Amazon Sellers Say Online Retail Giant is Trying to Help Itself, Not Consumers, WASH. POST (Oct. 1, 2019), https://www.washingtonpost.com/technology/2019/10/01/amazon-sellers-say-online-retailgiant-is-trying-help-itself-not-consumers/.

${ }^{315}$ Buying of labor or service shares would be required for any resource that is not expended on a one-to-one basis with output. A single cleaning of a fulfillment center floor supports the fulfillment of many orders, so a particular seller obtaining cleaning services for a particular order must buy a share of the cleaning service, rather than hire a cleaner to clean specifically for that order. This is just the familiar problem of fixed costs. See VARIAN, supra note 137, at 362 .

316 See Chris Pike, Competition and Open API Standards in Banking, No. ID 3487628, 2 (2018) (stating that "an API allows one piece of software to use another application's data or functionality").

${ }^{317}$ See supra note 309 and accompanying text.
} 
standardized form to any firm wishing to bring a rating algorithm to the data and then sell the results on to buyers. The monitoring of workers in order to generate the data required for rating algorithms to be applied is itself a separate component of an overall ratings system and would also need to be disintegrated from Amazon. To comply, Amazon would need to permit firms to bid for scarce space in the eaves of Amazon's fulfillment centers, wherein to place cameras to track worker performance. And so on, ad infinitum. All this, even before considering that fulfillment centers themselves are agglomerations of many inputs, only some of which may be essential, and therefore would themselves need to be further disintegrated into markets for each of their component parts. ${ }^{318}$

Each disintegration would transform a component decision that is at least potentially efficient into one that is necessarily inefficient. The reason is that although it is possible for an input monopolist to disintegrate vertically from a particular downstream component, it is not possible for an input monopolist to relinquish all control over how the downstream component is selected. For the terms according to which the input monopolist interacts with downstream

318 The only limit on the infinite regress of this disintegration is the requirement that the essential input be essential for competition in each of the disintegrating input markets. See supra note 302. The fulfillment centers must be essential for third-party sellers to participate in retail, otherwise Amazon need not disintegrate from retail. And the centers must be essential for participation in the labor market - something that is likely to be true for centers located in smaller local labor markets - otherwise Amazon need not disintegrate from labor. See Unfulfillment Centres - What Amazon Does to Wages, https://www.economist.com/united-states/2018/01/20/what-amazon-does-to-wages

(arguing that wages are lower in communities in which Amazon has opened fulfillment centers because Amazon is a monopsony buyer of labor). In general, the more specialized a downstream component must be to be used with the essential input, the more likely that the essential input will be essential in relation to the downstream component and therefore the more likely that the Warren rule would require that the input monopolist disintegrate from it. See Williamson, supra note 211, at 95-96 (discussing the key role played by "asset specificity" in determining whether a market will exist in a particular component). An Amazon frontend is likely be highly specialized, because it must be built to interface with Amazon's unique distribution system. As a result, Amazon's fulfillment centers are likely an essential input into the production of an Amazon web frontend as well, and so the Warren rule would therefore require that Amazon disintegrate from frontends.

It is worth noting that transaction cost economics generally dictates the opposite result: that the more specialized the component, the greater the economic rationale for integration, because the less likely it is that a market can in fact be created in the component, as it is unlikely that there will be any buyers of the component other than the owner of the essential input, leading to the possibility of wasteful bilateral monopoly bargaining between the owner of the essential input and the maker of the component. See id. By targeting platforms, understood as essential inputs, for disintegration, the Warren rule compels disintegration in those components in which functioning component markets are least likely to exist. See supra note 302 . 
firms, no matter how neutral, necessarily exclude some firms and favor others. Even a firm selling a standardized commodity, such as flour to bakers, exerts some control over which bakers can compete in the baking market in virtue of the location in which the flour seller chooses to sell (the closer bakers are favored), the size of the packages in which the flour seller supplies its flour (larger packages favor larger bakers), and so on.

The crafting of the terms according to which competition takes place is not vertical integration so long as the terms are applied neutrally and do not end up excluding too many downstream firms from the market. ${ }^{319}$ But the control inherent in crafting the terms does mean that the process of choosing the best downstream components is divided between two decision-makersthe input monopolist and consumers - and divided decision-making is constrained, and hence suboptimal, decision-making except in the limiting case in which the constraint does not bind. ${ }^{320}$ Consumers can pick the best of the components that fit the interface created by the input monopolist, but they cannot adjust the interface if they need to do so to get the best possible result. ${ }^{321}$ Similarly, the monopolist can steer consumers toward the optimal choice but cannot ensure that they choose it. ${ }^{322}$ While this does not mean that vertical disintegration is always inefficient — consumers might do so much better of a job at optimizing that it compensates for any costs associated with the constraint - it does mean that each disintegration potentially eliminates an optimum, by depriving the firm of full control over the choice of component.

But if a rule against competing on your own platform would implicate virtually all product components, why is it that some seem ripe for disintegration whereas others do not? Why do critics of Amazon understand the rule against competing on your own platform to require disintegration from retail but not disintegration from labor, or website frontends ${ }^{323}$ The answer would seem to be that once a firm has demonstrated the possibility of

\footnotetext{
${ }^{319}$ See supra note 302 . If the ground rules exclude too many firms, they start to look like a policy of favoring some firms over others, in which case they become discriminatory and therefore an instance of vertical integration.

320 See William J BAUMOL, ECONOMIC THEORY AND Operations ANALYSIS 62 (4th ed. 1977) ("The relationship between a constrained and an unconstrained maximization problem can be illustrated with the aid of a geographic analogy. If we seek the location of the highest point on earth, we will end up with the latitude and longitude of the peak of Mount Everest. But if this altitude maximization problem is constrained by the condition that we must remain within the continental limits of the United States . . . the height of the maximum point will be decreased. Of course, if the constraint had instead only required us to stay within the Asiatic continent ... our original [unconstrained] answer would have remained valid.").

${ }^{321}$ See id.

${ }^{322}$ See id.

${ }^{323}$ See Warren, supra note 14.
} 
disintegration, by engaging in it, the imagination of critics is fired. Thus there is a strong reality bias in current debates, just as there was in mid-century antitrust enforcement, one that is likely to be arbitrary and unreasonable..$^{324}$ For the fact that a firm has chosen to experiment in disintegration does not mean that disintegration is necessarily efficient going forward. ${ }^{325}$ Just as a firm's failure to disintegrate is no evidence that the firm's integration is efficient, rather than driven by strategic ends. ${ }^{326}$ The fact that Amazon has chosen partially to disintegrate from retail by allowing third-parties to sell on Amazon.com while still selling some merchandise for its own account says no more about whether retail is more efficient when disintegrated than the fact that Home Depot has chosen not to disintegrate tells whether Home Depot is more efficient as a vertically integrated firm. To target a firm for continued disintegration based on the fact that it is already disintegrated to some extent is to be pulled along by events rather than by analysis. Indeed, news reports regarding shoddy and dangerous products sold on Amazon suggest that Amazon may actually have already disintegrated too far: consumers have proven unable to sort good third-party sellers from bad on their own and need Amazon's help dictating to them which products are safe and which not. ${ }^{327}$

\section{The Place of Antitrust In the State}

Senator Warren's rule fails to reflect the lesson of the state's approach to the exercise of power that the heart of liberty is control over the prices charged by input monopolists rather than the exit of input monopolists from downstream operations. ${ }^{328}$ Nineteenth Century liberals understood this, which is why they did not ultimately demand constitutionalized economic rights, but rather only constitutionalized voting rights. ${ }^{329}$ Those voting rights ensured that tax rates would be kept low, so that regardless whether the government integrated vertically or not, the public would remain immune to

\footnotetext{
${ }^{324}$ See supra Section III.B.1.b.

${ }^{325}$ Cf. Verizon Commc'ns Inc. v. Law Offices of Curtis V. Trinko, 540 U.S. 398, 409 (U.S. 2004) (ignoring the possibility that a prior profitable course of dealing might have been terminated because the dealing became unprofitable in the course of arguing that terminations of prior profitable courses of dealing are suspect).

${ }^{326}$ Cf. id.

327 See Alexandra Berzon Scheck Shane Shifflett and Justin, Amazon Has Ceded Control of Its Site. The Result: Thousands of Banned, Unsafe or Mislabeled Products, WALL ST. J. (Aug. 23, 2019), https://www.wsj.com/articles/amazon-has-ceded-control-of-its-site-theresult-thousands-of-banned-unsafe-or-mislabeled-products-11566564990.

${ }^{328}$ See supra Section III.B.2.

${ }^{329}$ See supra Section III.B.2.
} 
redistribution in favor of the state. ${ }^{330}$ That created space for policy regarding vertical integration to focus on how most efficiently to organize a supply chain. ${ }^{331}$

That does not mean, however, that the best alternative to Warren's proposed rule would be to convert industry into consumer cooperatives, as some supporters of Warren's plan have also advocated. ${ }^{332}$ Cooperatives are already common in industries in which consumers are sufficiently permanent in their relationships with firms to enable effective consumer governance. ${ }^{333}$ Where this does not hold, imposing the cooperative form will not get prices down. ${ }^{334}$ But unlike in the case of the security monopoly, above which there is no independent force capable of imposing law, necessitating reliance on democratic governance to serve as a check on government exercise of pricing power, government itself stands above the business firm and is capable of regulating the prices that input monopolists charge, through the well-worn institution of administrative rate regulation. ${ }^{335}$ Rather than call for a blanket rule of vertical disintegration, Senator Warren should be calling for price regulation of input monopolists, which would recreate, through the decisions of independent agencies, the ceiling on taxation that public law today makes possible through democratic governance of the state.

In theory, price regulation is a complete solution to the problem of the exercise of power. Price regulation prevents firms from redistributing wealth by charging excessive prices, and that should deter firms from engaging in inefficient vertical integrations. For a careful price regulator must set prices so as to provide a reasonable return on a reasonable level of investment, and expenditures on inefficient vertical integration would not count as a reasonable level of investment. ${ }^{336}$ The regulator would set a below-cost price

\footnotetext{
${ }^{330}$ See supra Section III.B.2.

${ }^{331}$ See supra Section III.B.2.

332 See Sandeep Vaheesan \& Nathan Schneider, Cooperative Enterprise as an Antimonopoly Strategy, 124 PENN ST. L. REV. 1, 7-9, 15-16 (2019) (arguing that the size of companies like Google, Amazon, and Facebook is driven by the fact that they are investor owned and arguing that the cooperative form of business structure should be considered as an alternative by policymakers in an age of market concentration); Sheelah Kolhatkar, How Elizabeth Warren Came Up with a Plan to Break Up Big Tech, THE NEW YoRKER, https://www.newyorker.com/business/currency/how-elizabeth-warren-came-up-with-aplan-to-break-up-big-tech.

333 See HANSMANN, supra note 291, at 173-76 (explaining that utility cooperatives tend to be rare in cities, relative to rural areas because city-dwellers are relatively transient).

${ }^{334}$ See id.

${ }^{335}$ See id. at 180 (discussing the success of rate regulation relative to consumer cooperatives as a mode of restraining monopoly power in the public utility context).

336 See VISCUSI ET AL., supra note 197, at 544-45 (discussing prudence reviews in rate regulation).
} 
for inefficient integrations, deterring the firm from engaging in them. ${ }^{337}$ But in practice price regulation tends to take costs as given, and so would provide a reasonable return on an inefficient vertical integration as much as on an efficient vertical integration. ${ }^{338}$ That is true even in the context of the state. Voters' insistence on low taxes, combined with rules against corruption that ensure that tax dollars are spent on projects designed to benefit the public, do not in themselves tend to preclude all inefficient vertical integrations by the state. ${ }^{339}$ Government provision of telecom services, for example, would not count as corruption, and might not lead to a large enough increase in taxes for voters to object. ${ }^{340}$ A separate debate over the desirability of integrationof the merits of government provision in relation to private provision-tends to govern the problem of vertical integration at the level of the state. ${ }^{341}$ In the case of a private monopoly governed by a price regulation regime, antitrust fulfills this function, asking, through the rule of reason, whether the firm's decision to integrate vertically is good for consumers or bad. ${ }^{342}$ Thus the embrace of price regulation for input monopolists, as opposed to the imposition of a blanket prohibition on vertical integration, would complement antitrust as it currently operates, eliminating the redistribution that antitrust cannot address, while leaving antitrust free to continue to condemn vertical integration when it is inefficient and harmful to consumers but to preserve it when that is not the case.

\section{CONCLUSION}

Despite its traditional application to the business context, antitrust law's definition of power is extraordinarily broad. For antitrust's definition of market power as the power profitably to raise price reduces to the far more abstract power to command obedience without suffering so much dissent as to make the command no longer worthwhile, a definition familiar to any statesman as the essence of political power. The coincidence of antitrust's definition of power with that of political power generally suggests that

\footnotetext{
${ }^{337}$ See id.

${ }^{338}$ See id. at 539-41 (discussing "traditional rate of return regulation").

${ }^{339}$ See supra Section III.B.2.

${ }^{340}$ See RiCHARD R JOHN, NETwORK NATION: INVENTING AMERICAN TELECOMMUNICATIONS 395-96 (2015) (discussing the nationalization of the telephone system during World War One).

${ }^{341}$ See, e.g., Sappington \& Sidak, supra note 15, at 479-85, 516 (arguing that state-owned enterprises in the United States compete unfairly with private enterprise, but making this argument while only mentioning the issue of inefficient expenditure of tax dollars by stateowned enterprises only once).

342 See supra Section III.B.1.b.
} 
antitrust's mission, which is to regulate the acquisition and exercise of power, may in fact be coincident with the mission of all law generally. And so it is. All law, both public and private does no more than to regulation the acquisition and exercise of power. Public law, including constitution law, criminal law, and administrative law, regulate the acquisition and exercise of power by the state, understood as an enterprise that monopolizes the provision of physical security. Private law, including property law, tort law, and contract law, regulate the acquisition and exercise of power by private person with respect to goods and services other than security. Antitrust, as traditionally limited to the business context, supplements private law rules regarding the acquisition and exercise of power over non-security inputs.

Antitrust and the rest of the law both regulate the acquisition and exercise of power, but not always in the same way. Public law imposes a de facto limitation on the ability of the state to raise the prices it charges, in the form of taxation, for provision of the security input. The right to vote guaranteed by constitutional law gives consumers control over that price and they use their power to limit it. By contrast, the courts have long held that the antitrust laws do not prohibit the charging of high prices, only the inefficient centralization of control over a particular type of input (horizontal collusion or merger) or the inefficient integration into downstream inputs (vertical merger or integration).

This suggests a superior alternative to current proposals to strengthen the antitrust laws by prohibiting firms from competing on their own platforms. Those proposals would prohibit vertical integration, which would be both unworkable and inefficient, because all products are collections of components and so all firms are vertically integrated to some extent. The proposals would also be ineffective, because they would not eliminate the platform monopolist's control over the platform and hence power to charge those who use the platform exorbitant prices. Instead, antitrust reformers should take a page from public law's approach of limiting the ability of a monopolist to charge high prices. That cannot be accomplished in the business context through a right to vote, but it could be accomplished by extended administrative rate regulation to cover all platform monopolists. 